\title{
Middle Palaeolithic Mode 3 lithic technology in the rock-shelter of Benzú (North Africa) and its immediate environmental relationships
}

\author{
José Ramos-Muñoz a, *, Darío Bernal-Casasola a , Antonio Barrena-Tocino a, \\ Salvador Domínguez-Bella ${ }^{\mathrm{b}}$, Ignacio Clemente-Conte ${ }^{\mathrm{c}}$, Eduardo Vijande-Vila ${ }^{\text {a }}$, \\ Juan Jesús Cantillo-Duarte ${ }^{\text {a }}$, Sergio Almisas-Cruz ${ }^{a}$ \\ a Departamento de Historia, Geografía y Filosofia, Universidad de Cádiz, Avda. Gómez Ulla s.n, 11010, Cádiz, Spain \\ b Departamento de Ciencias de la Tierra, Universidad de Cádiz, Campus Río San Pedro, Puerto Real, Cádiz, Spain \\ c CSIC-Institución Milá y Fontanals (IMF), Departamento de Arqueología y Antropología, Grupo AGREST, Barcelona, Spain
}

\section{A R T I C L E I N F O}

\section{Article history:}

Available online 12 November 2015

\section{Keywords:}

Strait of Gibraltar

Historical region

Benzú rock-shelter

Hunter-gatherer groups

Mode 3 technology

\begin{abstract}
A B S T R A C T
The rock-shelter of Benzú is located near the city of Ceuta in North Africa. At the rock-shelter of Benzú there is a sequence of 7 archaeological levels, which are associated with a clearly defined Mode 3 lithic technology. The similarities with other assemblages found in the south of the Iberian Peninsula are clear. We emphasise the exploitation of marine resources by these hunter-gatherer societies from the beginning of the Middle Pleistocene sequence. On the basis of this archaeological evidence and in the context of recent studies on North Africa, this work assesses the possible relationships and contacts between societies on both shores of the historical region of the Straits of Gibraltar.
\end{abstract}

๑) 2015 Elsevier Ltd and INQUA. All rights reserved.

\section{The rock-shelter of Benzú: location, stratigraphy, chronology, and faunal and vegetation records}

A recent monograph presented the results of 10 years of interdisciplinary research on the rock-shelter and cave of Benzú (Ramos et al., 2013b). This work aims to provide an overview of the lithic technology associated with the site in its regional context.

The rock-shelter of Benzú is located in Ceuta, and it opens onto an abrupt and near-vertical dolostone outcrop (Fig. 1). Part of the cover has collapsed, and its remains may be seen scattered throughout the site. Its current dimensions are $15.52 \times 6.2 \mathrm{~m}$. The southeasternmost end forms a small cave (Ramos et al., 2008a, 2014a, 2014b). The archaeological deposit covers an area c. $61.1 \mathrm{~m}^{2}$ and is over $5.50 \mathrm{~m}$ deep. The archaeological sequence consists of layers of cemented breccia with calcareous crust interspersed with layers of calcitic flowstone. Laterally, the depth of the archaeological deposit decreases to just over $1 \mathrm{~m}$, where it sits upon a sub-horizontal platform. The excavation identified 10 strata (Durán, 2003, 2004), 7 of which have evidence of human occupation (Fig. 2). This evidence includes large numbers of worked lithic remains, bones and shells. Micromorphology and the analysis of bioerosion processes have

\footnotetext{
* Corresponding author.

E-mail address: jose.ramos@uca.es (J. Ramos-Muñoz).
}

demonstrated that the erosive formation of the rock-shelter took place prior to the earliest human occupation, MIS 9 (Abad et al., 2007). The immediate hinterland of Benzú offered access to abundant food (marine, animal and plant) and lithic and water resources.

In previous works, we have explained in detail the methodology followed in the rock-shelter (Domínguez-Bella et al., 2012; Ramos et al., 2012, 2013b). Concerning chronology, several dating techniques have been applied (Calado, 2006). The sedimentary strata at the base of the sequence have been dated by TL (Bateman and Calado, 2003), and the age of the speleothems has also been calculated by U/Th (Durán, 2004). In parallel, experimental tests have been applied to these in order to calculate their age by TL (Benéitez et al., 2004). The dates recorded run between -(OSL) Shfd 020135: $254 \pm 17$ ka-in stratum 2 and $-(\mathrm{Th} / \mathrm{U})$ IGM: \pm 70 ka-in stratum 10. In conclusion, the most recent episodes in the sedimentary and archaeological sequence can be dated to before $70,000 \mathrm{BP}$, while the record of the earliest human occupation of the rock-shelter dates back approximately 250,000 years.

Considerable efforts have been made to record the micro-spatial distribution of the nearly 40,000 artefacts located on the site (36,092 specimens of worked stone, 3362 fragments of terrestrial fauna, 144 fragments of marine fauna, and other biological remains and samples), which has been very informative concerning the social activities carried out by the human groups that occupied the rock-shelter (Ramos et al., 2013b: 455-477). 


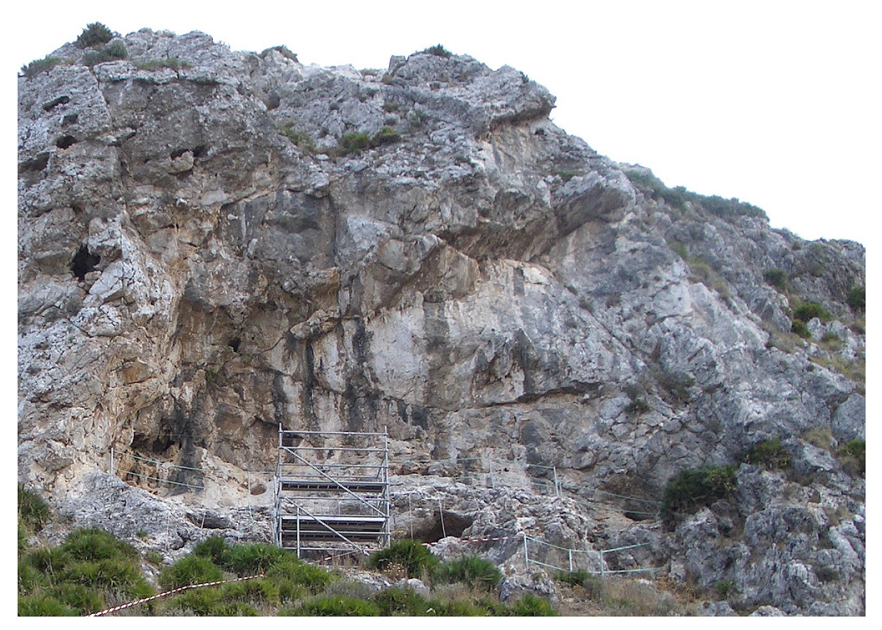

Fig. 1. View on the Benzu rockshelter.

The results of the pollen studies are reflective of Mediterranean climatic conditions, with alternation between xeric and steppic taxa and mesophile coastal taxa and Cyperaceae. This is indicative of the alternation of dry and more humid conditions in the sequence. There is also evidence for a drop in temperature, as indicated by the presence of Pinus and Juniperus (Ruiz Zapata and Gil, 2013: 271-277). Anthracological evidence indicates the presence of bushes: Erica sp. in stratum 4 and Fabaceae in stratum 2. These two taxa burn well and could have been used as fuel by the human groups occupying the shelter during these periods (Uzquiano, 2013). Mammal bone remains, in the form of mid-sized fragments and splinters, were brought to the cave by human action. Areas of activity and possible areas of consumption have been recorded in strata 4,5 and 6 . A large number of the bone fragments show signs of intentional breakage and burning. The assemblage is especially rich in ungulate remains - mid-sized bovines and other herbivores (Monclova et al., 2013). Benzú also yields evidence of the

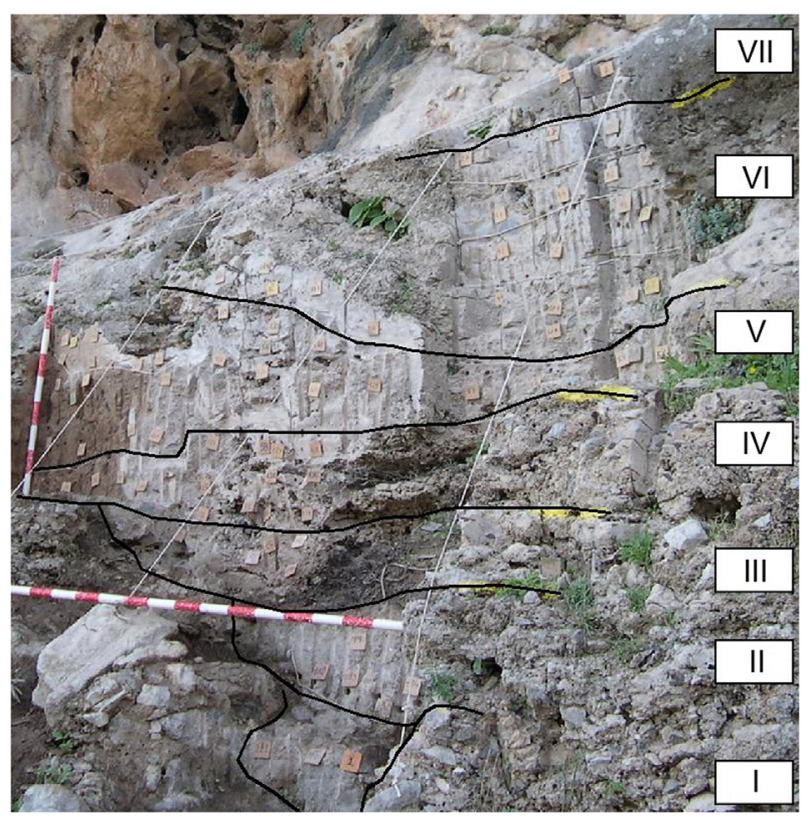

Fig. 2. Stratigraphic profile. exploitation of coastal resources. Malacofauna (essentially Patella) is present in the whole sequence (strata 7 to 1 ). Ichthyofauna is present in level 5a (Cantillo and Soriguer, 2011; Ramos et al., 2011a; Cantillo, 2012).

\section{Worked lithic remains}

The lithic remain assemblage is composed of 36,092 specimens (Ramos et al., 2013b: 339-437), from strata 1 to 7. Strata 4 and 5 have yielded the greatest numbers of such remains, which is indicative of more intense occupation periods.

\subsection{Lithology, catchment and use of raw materials}

The analysis of the lithic raw materials in Benzú was carried out by applying different archaeometric techniques (Domínguez-Bella, 2004). The target was the analysis of the geological, lithological and geomorphological characteristics of the rock-shelter's immediate environment, as well as the mineralogical, petrological and geochemical examination of the lithic materials found therein. The data collected is relevant for the study of archaeological questions relating to early human mobility. Specifically, the main techniques used were as follows: colorimetric characterisation by de visu observations aided by Munsell Soil Color Charts 1994, and petrographic observations, including transmitted-light petrographic microscopy, polarised-light petrographic microscopy, binocular magnifying glasses, electronic scan microscopy with EDS, X-ray diffraction, X-ray fluorescence and emission spectrometry ICP-MS.

We also took thin-section samples from geological materials found in the nearby environment as well as from the rock-shelter's worked stone tools. These thin sections were analysed using a transmitted-light optic microscope, which, using polarised light, yielded significant information regarding the texture, porosity, mineralogy, presence of fossils, etc. of different stone types.

A significant number of the lithic remains have been analysed (3659 specimens); all strata are represented in the sample (Domínguez-Bella et al., 2006, 2013: 316-338). Compacted sandstones are clearly predominant, comprising $61.03 \%$ of the sample (the total percentage of sandstones is 61.68\%) (Fig. 3: A). Radiolarites (Fig. 3: B) are the second most abundant stone type (red radiolarite $24.84 \%$, greens $8.55 \%$, grey $2.27 \%$, white $0.03 \%$, black $0.68 \%$; total $36.37 \%$ ). Other lithic types present are (Fig. 3: C, D): large flint fragments $(1.12 \%)$, dolostone $(0.38 \%)$, phyllite $(0.19 \%)$, other metamorphic rocks (0.005\%) and limestone (0.005\%). Compacted sandstones were most commonly used for the production of stone tools $(61.50 \%$ of cores, $72.10 \%$ of flakes, $54.30 \%$ of other debitage and $53.90 \%$ of retouched fragments). Radiolarites are again the second most abundant (33.34\% of cores, $25.38 \%$ of flakes, $43.14 \%$ of other debitage and $43.12 \%$ of retouched specimens). The two most common raw materials (sandstone and radiolarites) were collected locally and have been found in nearby geological units and along the coastline. Other stone types, which were brought to the site from elsewhere by the occupying groups, are much more rarely documented.

\subsection{Lithic technology}

Morphological features indicate that slightly abraded pebbles were predominantly selected (99.24\%), which explains the absence of evidence of erosive and post-depositional processes. We also examined other features, for example colour and patina, as well as elements such as fire exposure. The use of fire has been abundantly documented (archaeobotanic analysis, raw material analysis, and lithic technology and function analysis). Fire seems to have been used to clean the rock-shelter. 

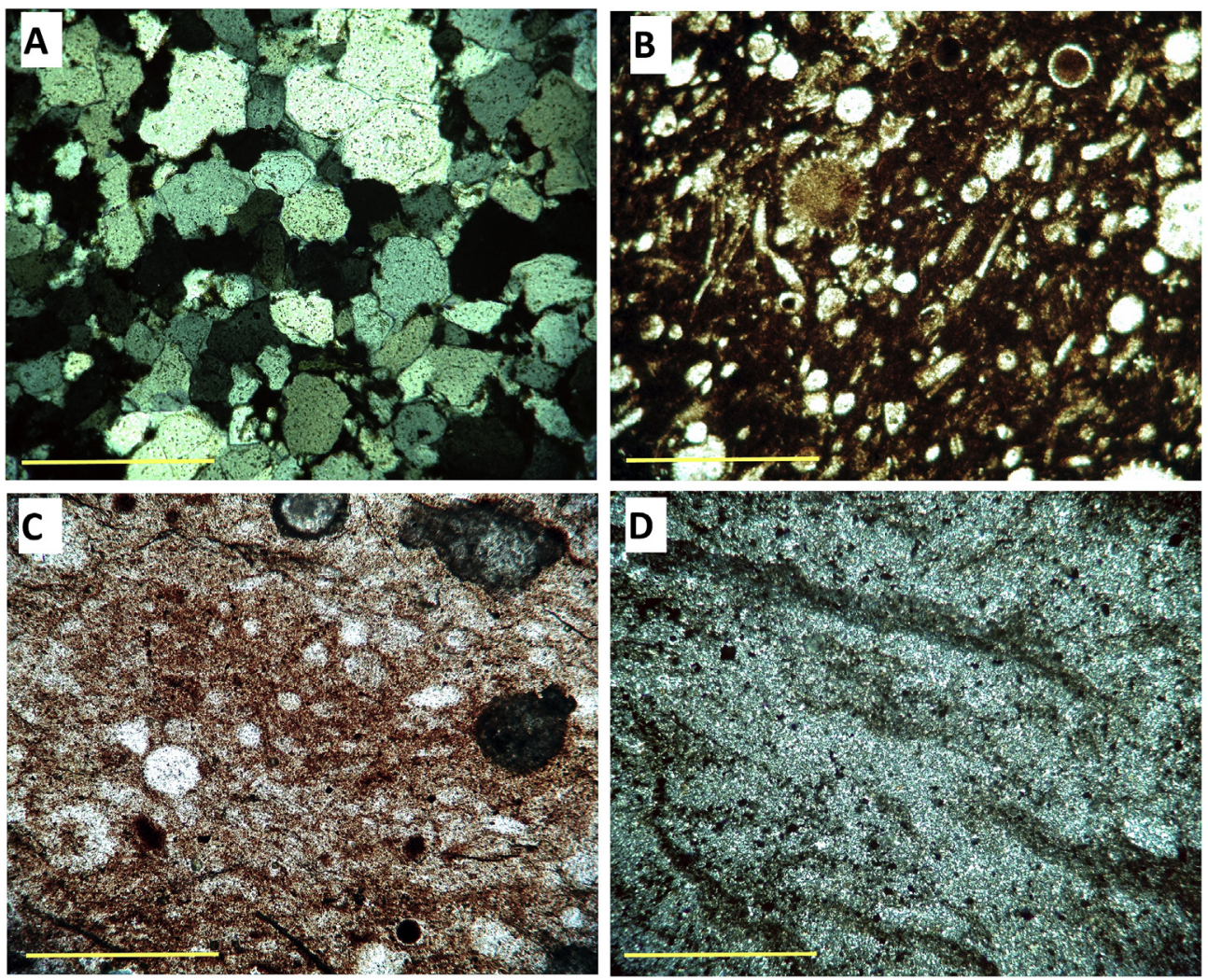

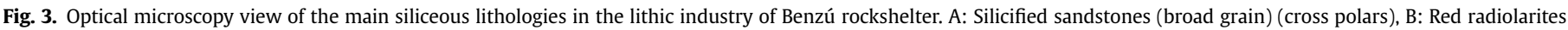
(paralel polars); C: Banded flint with radiolaries or spherical inclusions (paralel polars); D: Massive flint, with inclusions and fossil remains (cross polars). (Scale $=0.5$ mm).

Concerning the technical characteristics of lithic technologies at Benzú (Ramos et al., 2013a: 356-437), there is a limited number of natural bases $(\mathrm{nB})$, which we relate to the exhaustion of supply after their systematic use for the production of cores (1GNB-First Generation Negative Base). The analysis of knapping products and retouched pieces (Tables 1 and 2) indicates a clear predominance of the former $(35,322$ specimens: $97.89 \%)$ over the latter (763 specimens: $2.11 \%)$. The 7 strata under study have yielded a total of 523 cores (1.45\%). Flakes (PB-Positive Bases) are very abundant $(11,648$ specimens: $32.28 \%$ ). Other knapping products amount to 23,151 specimens (64.16\%): these include discards ( 7429 specimens), small flakes (15,720 specimens) and tabular plaquettes ( 2 specimens).

With regard to the technical aspects of production, the analysis of Indirect Technical Operative Themes (ITOTs) points to several techniques being used in order to exploit the bases and cores. The flakes so obtained could be used as tools in their own right or retouched in order to create retouched artefacts (2GNBs-Second Generation Negative Bases) (Ramos et al., 2013b: 678-682). The ITOTs analysis (Carbonell et al., 1999) revealed a clear relationship between cores-1GNB and flakes-PB, including 5 ITOTs: 1longitudinal, 2-unipolar, 3-centripetal, 4-bipolar and 5-multipolar (Ramos et al., 2013b: 678-682). The distribution of cores, flakes and other knapping products indicates that the knapping operations took place on site.

A total of 523 cores-1GNB have been located at the site $1.45 \%$ of the total assemblage). Cores worked by the application of recurrent methods, related to well-defined ITOTs, are clearly predominant. Polyhedric cores are the most abundant, with 207 examples (39.58\% of total number of cores). Multipolar centripetal (Fig. 4) are also present in significant numbers (189 specimens: $36.14 \%$ of cores). Along with Levallois-cores, they represent $41.71 \%$ of the total number of cores present in the assemblage. Eighty-three examples of unipolar cores were recorded (15.81\% of $1 \mathrm{GNBs}$ ). The assemblage also includes 12 bipolar 1GNBs (2.28\%), 1 example of a 1 GNB on flake $(0.19 \%)$ and 1 example of crested 1 GNBs $(0.19 \%)$. Other technical features of 1GNB-cores, such as their facial and centripetal character and the obliquity and depth of the front and sagittal edges, were also analysed (Ramos et al., 2013b: 371-372).

Flakes (PB or Positive Bases) are present in very significant numbers (11,648 specimens: $32.27 \%$ of the total assemblage). This includes a small number of flakes related to the initial steps in the knapping process: cortical flakes amount to 162 (1.39\% of total number of flakes), and semi-cortical flakes to 587 (5.04\%). The most abundant type are the internal flakes, with 8560 specimens (69.18\%). Levallois flakes (Fig. 5) are the second most abundant type (2267 specimens: $19.48 \%$ ). Seventy-two crested flakes (0.62\%) were also recorded. Flakes are much more abundant than laminar fragments (95.76\% and 4.24\% respectively) (Ramos et al., 2013a: 376-377). The morphological analysis of the flakes has also revealed a preference for broad, large flakes over small flakes (Bagolini, 1968). Flakes with visible butts are more common than those which have missing butts (78.56\% and $21.44 \%$ respectively). Among the former, faceted butts are clearly predominant over plain butts. Other technical features were also examined, for example the flakes' dorsal-, ventral- and butt-faces, as well as dimensions, fractures and volume (Ramos et al., 2013a: 377-379).

The application of knapping techniques was very regular, especially concerning the use of centripetal and Levallois cores for the production of Levallois flakes, which were subsequently retouched for the shaping of retouched artefacts (2GNB tools), especially scrapers and points. Retouching always followed highly standardised procedures. It has been detected that certain tools 2GNB-scrapers (Fig. 6: c-f), 2GNB-notched (Fig. 6: a,b) and 


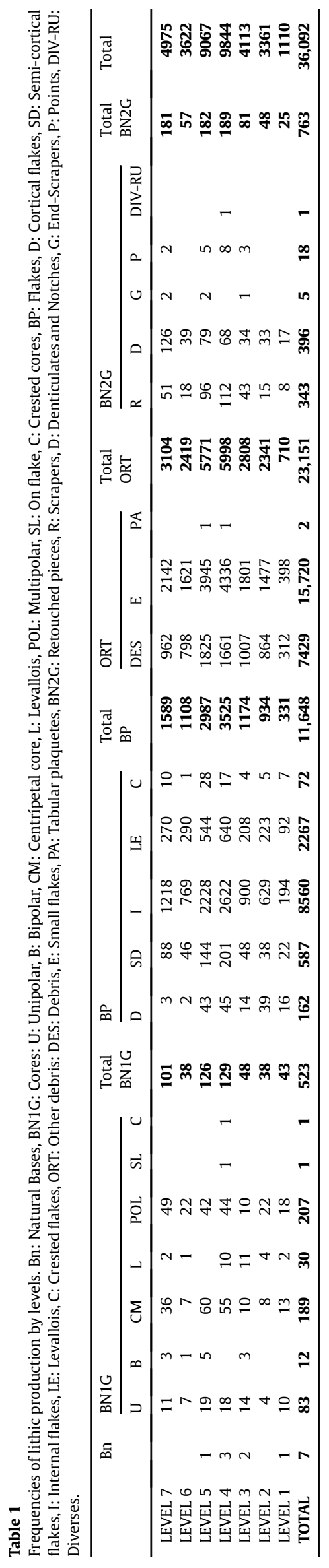

denticulated tools, and 2GNB-points - were especially often knapped from radiolarite or sandstone, internal or Levallois, medium-to-large flakes. They generally feature 3 or more edges, 4 to 5 extractions and different kinds of well-faceted butts.

Among BN2G-retouched flakes, a clear predominance of simple over multiple retouch can be noted, as well as deep over marginal, direct over inverse, and straight over denticulated retouches (Laplace, 1972: 113), including scrapers, denticulated tools and points (Ramos et al., 2013a: 392). In short, all strata present the typical typological features of Mode 3 technologies. Scrapers are predominant (343 examples: $44.95 \%$ ) in strata 3, 4 and 5, while notched tools (396: 51.90\%) predominate in strata 1, 2, 6 and 7. Points are present in significant quantities (18: $2.36 \%$ ), and a number of end-scrapers have also been recorded (5: $0.65 \%)$.

\subsection{Micro- and macro-analysis of lithic remains}

Wear trace analysis was carried out on a sample of tools which represented all 7 levels of human occupation in the sequence (Clemente, 2006, 2013: 438-454). This analysis resulted in the following conclusions:

1. Despite the hardness of the sediment - breccia - which required the application of unusual excavation strategies (Domínguez-Bella et al., 2012), the lithic artefacts suffered little because of this. Only a low percentage of artefacts suffered cuts or perforations during the process of block extraction. Another low percentage suffered some surface damage caused by the electrical chisels and metallic brushes used in the excavation of the blocks in the laboratory. This is especially evident in stratum 7, which was exceptionally hard to excavate.

2. The lithic artefacts in Benzú present no evidence of damage due to sedimentary pressure or dragging. Generally, edges are neither abraded nor rounded. The fractures in the sandstoneencrusted quartz crystals appear to be quite fresh, which is ideal for microscopic analysis. Homogenous stones (flint and radiolarite), however, are more vulnerable to taphonomic and post-depositional processes, and often have a glossy appearance. These kinds of rock are also more prone to suffering thermal alterations, or at least to showing clearer signs of them, including colour change, thermal gloss, cracking and thermal spots (Clemente, 1997a). We think that these thermal alterations could have been caused by direct contact with fire: according to our hypothesis, the occupants set the rock-shelter on fire every time they arrived with the intention of settling there. This had a prophylactic effect and would have facilitated settlement. On several occasions, especially in stratum 5 , tools that had been shaped previously and left on site (probably during the time period corresponding to stratum 4 ) were exposed to the action of fire and then retouched and used. This reuse of tools after they had suffered thermal alteration has been documented in other Middle Palaeolithic sites on the Iberian Peninsula (Clemente, 1995).

3. The lithic technology documented at Benzú was used in a variety of economic activities related to the exploitation of both animal (Fig. 7) and plant resources. Use wear has been detected in nearly $20 \%$ of the specimens included in the total sample analysed. It has been concluded that woodworking was carried out with scrapers and also with other types of tool; scrapers were used both for cutting longitudinally (sawing) and for scraping transversally (Fig. 8). Soft tissues were cut using tools whose active edges had not been retouched, in contrast to tools used for cutting hides; in these cases, the retouch is generally direct and deep. Wear trace analysis also indicates that, in most strata, the proportion of tools used for processing animal tissues 
Table 2

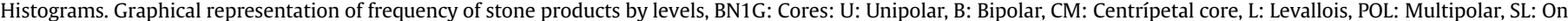

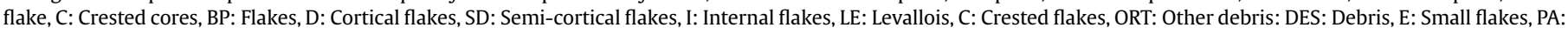
Tabular plaquetes, BN2G: Retouched pieces, R: Scrapers, D: Denticulates and Notches, G: End-Scrapers, P: Points, DIV-RU: Diverses.
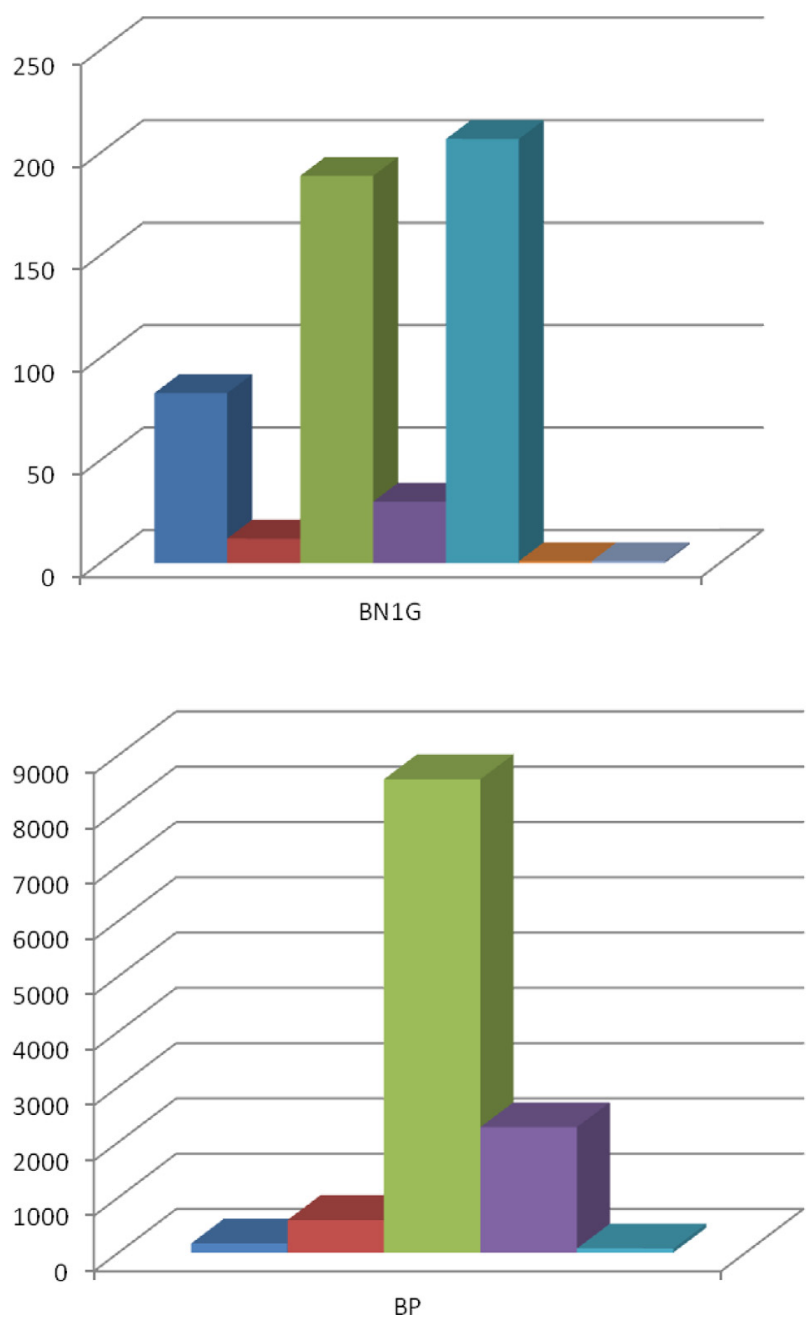

- BN1G-U=83 (15,87\%)

- BN1G-B= $12(2,29 \%)$

BN1G-CM= $189(36,14 \%)$

- BN1G-L= $30(5,74 \%)$

口 BN1G-POL=207 (39,58\%)

- $\mathrm{BN} 1 \mathrm{G}-\mathrm{SL}=1(0,19 \%)$

BN1G-C= $1(0,19 \%)$

\author{
- BP-D= $162(1,39 \%)$ \\ - BP-SD= $587(5,04 \%)$ \\ - BP-I= $8560(73,49 \%)$ \\ n BP-LE $=2267(19,46 \%)$ \\ - BP-C $=72(0,62 \%)$
}

is similar to that of tools used for processing vegetal resources. However, the tools recovered from stratum 3 are mostly related to the processing of animal tissues.

4. Hafting was a technological leap forward for prehistoric societies: it allowed for more efficient tools at a lower labour cost. Archaeologists have found very early evidence for this practice (Rots and Van Peer, 2006; Rots, 2010), and residues of the mastic used as glue have even been found in Near Eastern Middle Palaeolithic contexts (Boëda et al., 1998). On both sides of a pointed flake found in Benzú we can note a series of extractions - these were aimed at trimming down the area were the shaft was located. Moreover, one of the edges presents evidence of micropolishing and some crystal alteration that can be associated with its sustained contact with a wooden shaft (Fig. 8).

5. The hinterland of Benzú has ample supplies of lithic raw material. For this reason, blunt tools were not reshaped of sharpened, but replaced by fresh tools; this is especially the case with sandstone tools, which are particularly prone to blunting. As a consequence, sandstone tools were used for short periods of time, and the traces of wear are tenuous, which makes their detection difficult. Heterogeneous stone types, in contrast, are more resistant to blunting and wear traces are easier to identify (Clemente, 1997b; Clemente and Gibaja, 2009).

\section{Synthesis of lithic technology at Benzú}

We may say that the settlement is rich in natural bases $(\mathrm{nB})$ with which cores were elaborated (1GNB). These, in turn, were knapped for the production of flakes (PB), a process that also produced large quantities of debitage. Flakes were later used for the production of retouched artefacts (2GNB), including scrapers, notched tools, denticulated tools and points. Both flakes and 2GNB tools were used in the economic activities characteristic of hunter-gatherer groups (Ramos et al., 2013b: 339-437).

No significant technical changes can be attested in the sequence, which is of great interest concerning Mousterian technologies in general (Bordes, 1978; Binford, 1983, 1985; Geneste, 1991; Stiner and Kuhn, 1992; Kuhn, 1995; Mora et al., 2008; Villaverde et al., 2012). It seems fairly clear that this regularity was caused by the intergenerational transmission of knowledge: these groups were technologically conservative and adapted their instruments to their economic needs (hunting, gathering and the exploitation of marine resources). 
Table 2

(continued)

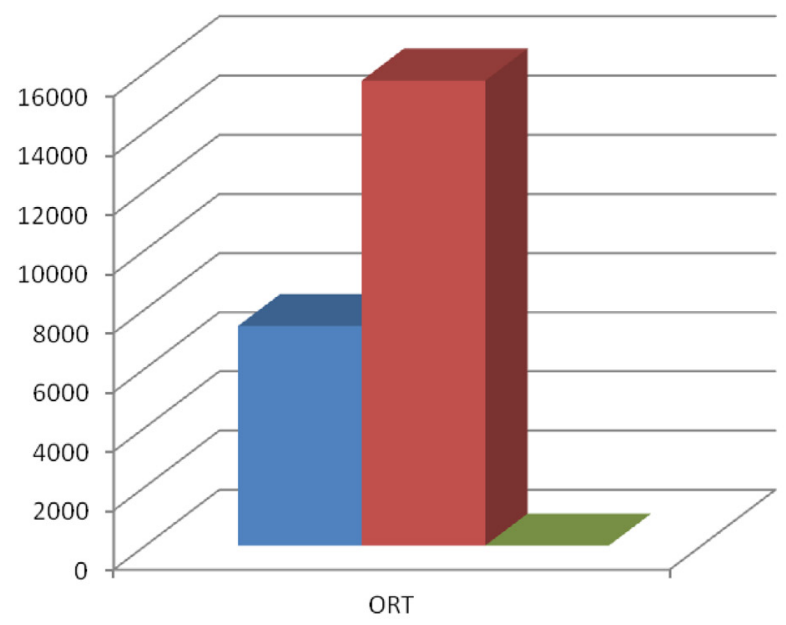

— ORT-DES $=7429(32,09 \%)$

- ORT-E= $15720(67,90 \%)$

- ORT-PA $=2(0,01 \%)$

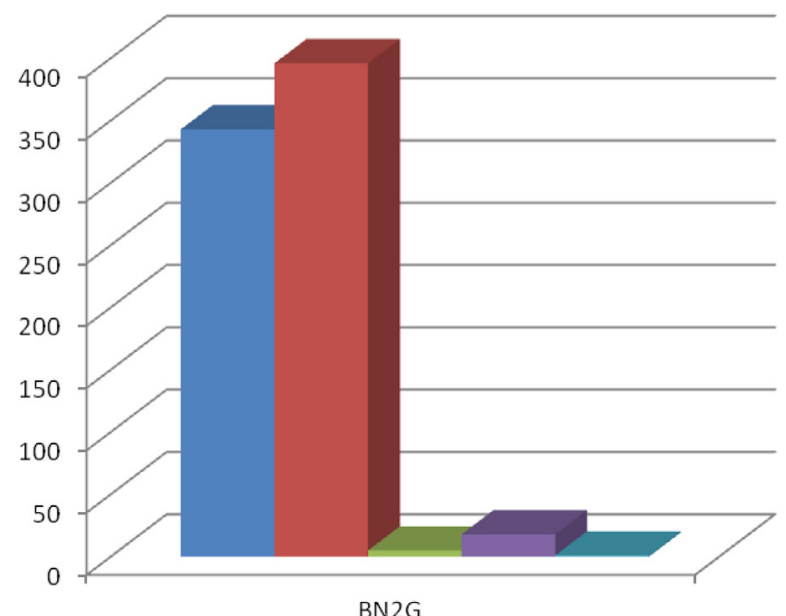

- BN2G-R $=343(44,95 \%)$

- $\mathrm{BN} 2 \mathrm{G}-\mathrm{D}=396(51,90 \%)$

- BN2G-G $=5(0,66 \%)$

- BN2G-P= $18(2,36 \%)$

= BN2G-DIV-RU $=1(0,13 \%)$

The functional analysis of the knapped products reveals that woodworking was practised in all seven archaeological strata to a greater extent than either butchering or hide processing. In stratum 3 , however, butchering was the most common activity. Furthermore, it was also the only level in which the scraping of an animal hard tissue has been documented. Thermal alterations were present to a significant degree, which indicates the burning of the rockshelter at the beginning of each habitation episode. In stratum 4 , there is evidence for the hafting of an instrument (Clemente, 2013).

In conclusion, lithic technology in Benzú is uniformly characteristic of Mode 3, with a clear predominance of the Levallois technique and centripetal cores. Concerning flakes, internal flakes are predominant, but both those generated in the early stages of knapping and Levallois flakes are also well represented. With regard to retouched products, scrapers are particularly abundant, along with points and, to a lesser extent, notched and denticulated tools. Within the overall homogeneity of stone tools, some variation exists, as demonstrated by the percentage of Levallois productions between levels 3 and 4 .

\section{Benzú's territory}

The Rock-shelter of Benzú is not an isolated site, as a large number of sites with similar technology (Mode 3 ) have been found in the regions of Ceuta and Tétouan (Garriga and Tarradell, 1951; Posac, 1981; Ramos and Cantillo, 2011 c). Specifically, two survey campaigns carried out in Ceuta in 2001 and 2010 identified nine such sites (Fig. 9): 22-Loma de los Hornillos, 23-Tiro Pichón I, 25Playa Benítez, 73-Calamocarro, 74-Altabacal, 75-Punta de la Cabeza, 76-Zapatero III, 80-Los Olivillos and 81-Topete. The survey also encountered six instances of isolated finds: I.F. 8-Playa de Cala Mocarro, I.F. 17-Barranco de las Lanzas, I.F. 22-San Amaro, I.F. 23Hacho II-, I.F. 32-Casa de Zapatero IV and I.F. 33-Casa de Zapatero V (Bernal et al., 2003; Vijande et al., 2011). All of these sites and isolated finds are located in foothill areas of quaternary terrace deposits between Calamocarro and Benzú and on the hilly slopes of Ceuta's mountainous interior. Around Tétouan, up to 49 Mode 3related sites have been identified; these sites are located between Oued Liane and the coast of Tétouan and are informative concerning the mobility of the human groups that occupied Benzú and the rock-shelter's immediate hinterland (Ramos et al., 2008b, 2011b).

The excavation of Benzú yielded no evidence for the existence of Aterian technology at the site. Around Ceuta, the only evidence for Aterian technology was found in contexts in Cerro de Isabel IIEstación Radio (Bernal et al., 2003); also, an Aterian-type notched point was found in 78-Loma del Tío Díaz IV (Ramos et al., 2011c). Around Tétouan, evidence for Aterian industries was found in three 

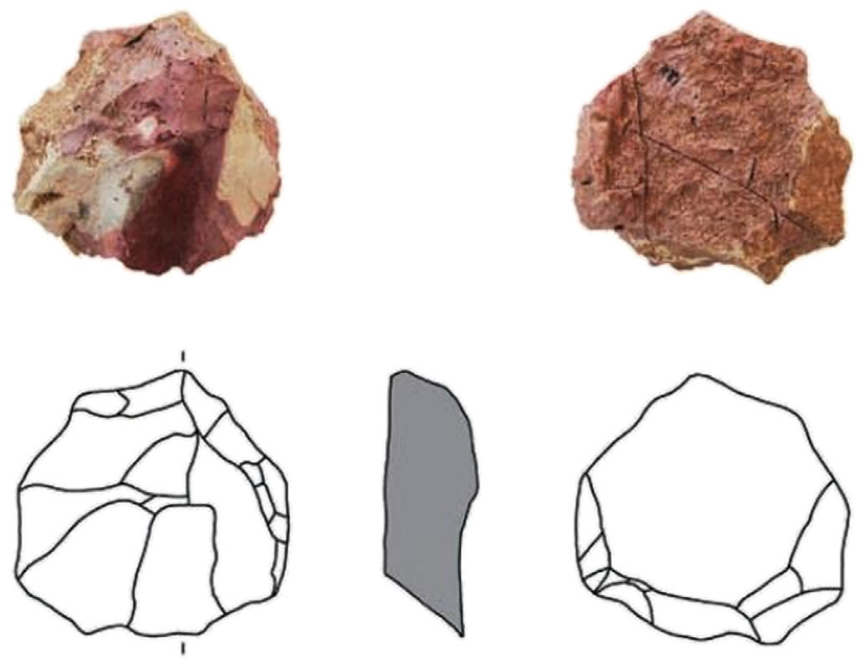

a
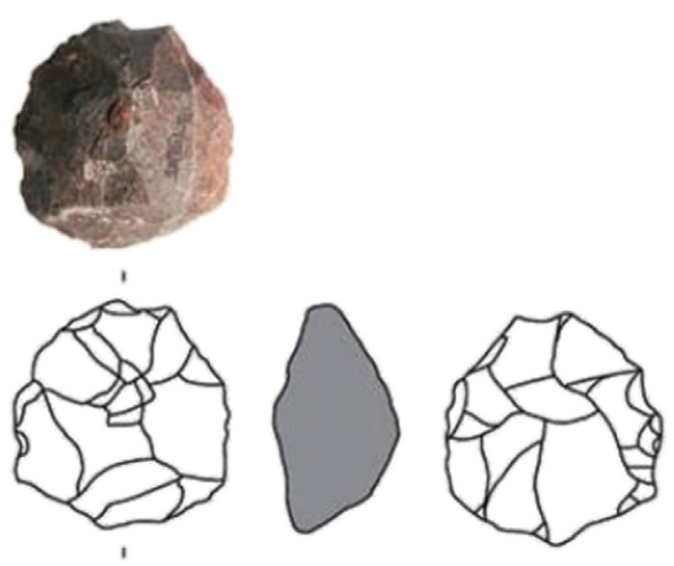

b
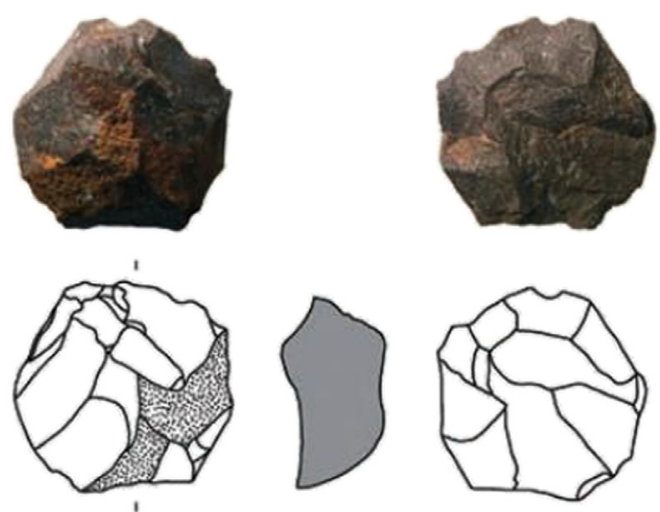

C

0

$10 \mathrm{~cm}$

Fig. 4. Centripetal cores. (a) Level 2, (b) Level 3, (c) Level 4.

surface locations (Ramos et al., 2008b, 2011b). In addition, several excavations yielded stratigraphic evidence of Palaeolithic sequences, for example in the caves of Caf That el Gahr (Tarradell, 1958; Ramos et al., 2008c), Gar Cahal, Kehf el Hammar and Hattab 2 (Barton et al., 2005; Bouzouggar and Barton, 2006; Bouzouggar et al., 2006), and also, near Tangier, in Cap Achakar and the cave of Mugaret el'Aliya (Otte et al., 2004; Bouzouggar and Barton, 2006: 123).

Recent evidence suggests that the chronology of North African Aterian technologies is higher than was previously thought (Nespoulet et al., 2008a, 2008b; Garcea, 2010; El Hajraoui and Nespoulet, 2012). In the important sequence of Ifri N'amar (Nami and Moser, 2010), tanged tools have been dated to as early as $145 \pm 9 \mathrm{ka}$, which is even earlier than Mode 3 and demonstrates the technological and chronostratigraphic variability of North African Middle Palaeolithic sequences (Nami and Moser, 2010: 263; Linstädter et al., 2012). The intermingling of Aterian and Mode 3 North African Middle Palaeolithic sequences is becoming increasingly clear (Collina-Girard and Bouzouggar, 2013). Aterian technology is also part of the Mode 3 Lithic technology.

In addition, we must also stress the clear relationship between lithic technologies in this region of North Africa and those found in the south of the Iberian Peninsula (Lumley, 1969; Botella and Martínez, 1979; Vallespí, 1986; Vega et al., 1988; Barroso and De Lumley, 2006; Medianero et al., 2011; Ramos Fernández et al., 2011-2012; Cortés et al., 2011, 2011-2012), especially the area around the Straits of Gibraltar (Ramos, 2008; Jennings et al., 2009; Bernal Gómez, 2012; Giles et al., 2012).

\section{Regional contextualisation of Mode 3 hunter-gatherer groups in NW of Africa}

The definition, distribution and composition of Mode 3 technologies in North Africa (Fig. 10) is a classic archaeological problem (Balout, 1955; Vaufrey, 1955; Camps, 1974; Bordes, 1976-1977). Most sites that have been identified to date are open-air and stratified, and well-dated sites are scarce. Generally, identification has relied on the presence of points and scrapers. The site of Djebel Irhoud yielded a standard Mousterian assemblage found in association with anthropological remains, which were initially identified as Neanderthals (Ennouchi, 1962). Another example is the Cave of Dar es-Soltan, the study of which began in the 1950s, where Mousterian, Aterian and Neolithic technologies were found (Ruhlmann, 1951). These technologies have also been found in the vicinity of Ceuta and on the terraces of the Martil River, near Tétouan (Tarradell and Garriga, 1951), as well as on the coastal terraces near Ceuta and Beni Gorfet (Morán, 1941). Posac (1956) also identified Mousterian technologies near Melilla and Nador (Bravo and Bellver, 2004). Pericot and Tarradell (1962) compiled the results of the investigations carried out in the 1950s on the origin of these industries, as well as on their technological definition, stratification and relationship with previous technologies.

In 1984, Hahn constructed a general overview of the Palaeolithic sequence in North Africa and southern Europe (Hahn, 1984) followed in 1992 by Nehren, who synthesised the problems of interpretation that exist around Mousterian technology; in his opinion, Mousterian technologies began before $100 \mathrm{ka}$ and were related to the Late Acheulean period (Nehren, 1992).

In recent years, there has been renewed interest in the issue, as shown by the works of several archaeological projects. The work of the Mission Archéologique et Paléontologique Française au Maroc has generated new data. In this context, The Mission au Maroc Oriental has undertaken the synthesis of the evidence from the caves of Djebel Irhoud, Kifan Bel Ghomari and Pigeons in Taforalt (Wengler, 2001), as well as a detailed analysis of the Cave of Rhafas (Wengler et al., 2001; Mercier et al., 2007). The French-Moroccan mission has also worked in the region of Rabat-Témara, where very interesting results are being obtained, including evidence for the high chronology of Aterian technologies (Nespoulet et al., 2008a, 2008b, 2011; Schwenninger et al., 2010; El Hajraoui and Nespoulet, 2012). 

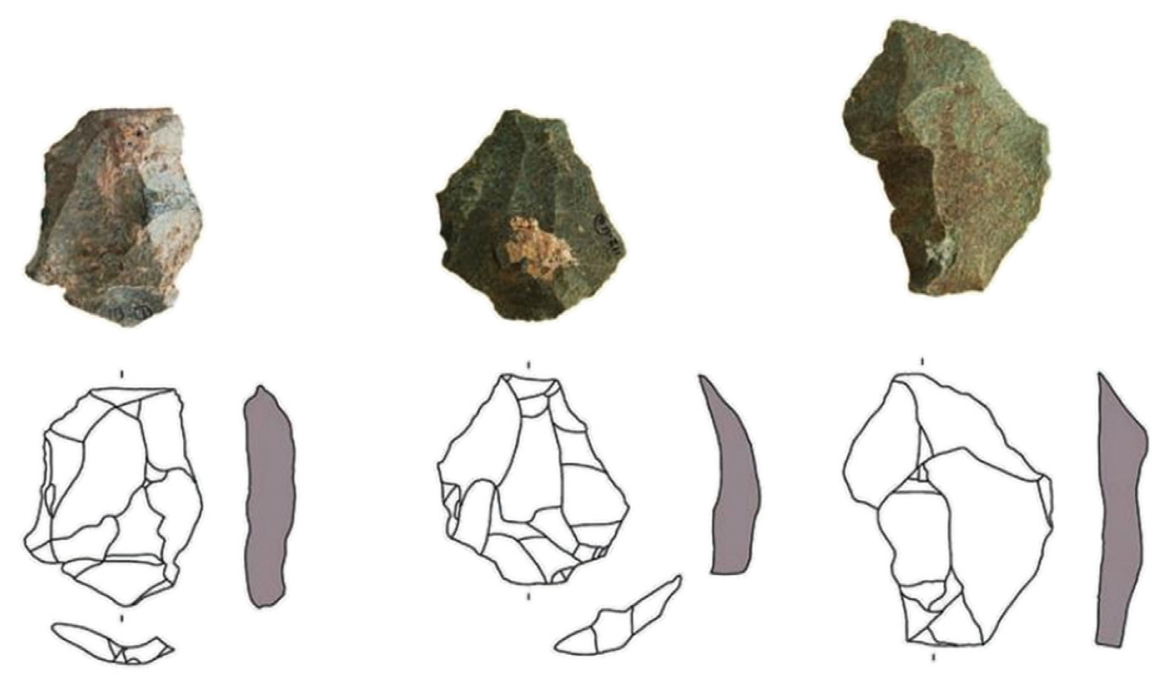

a
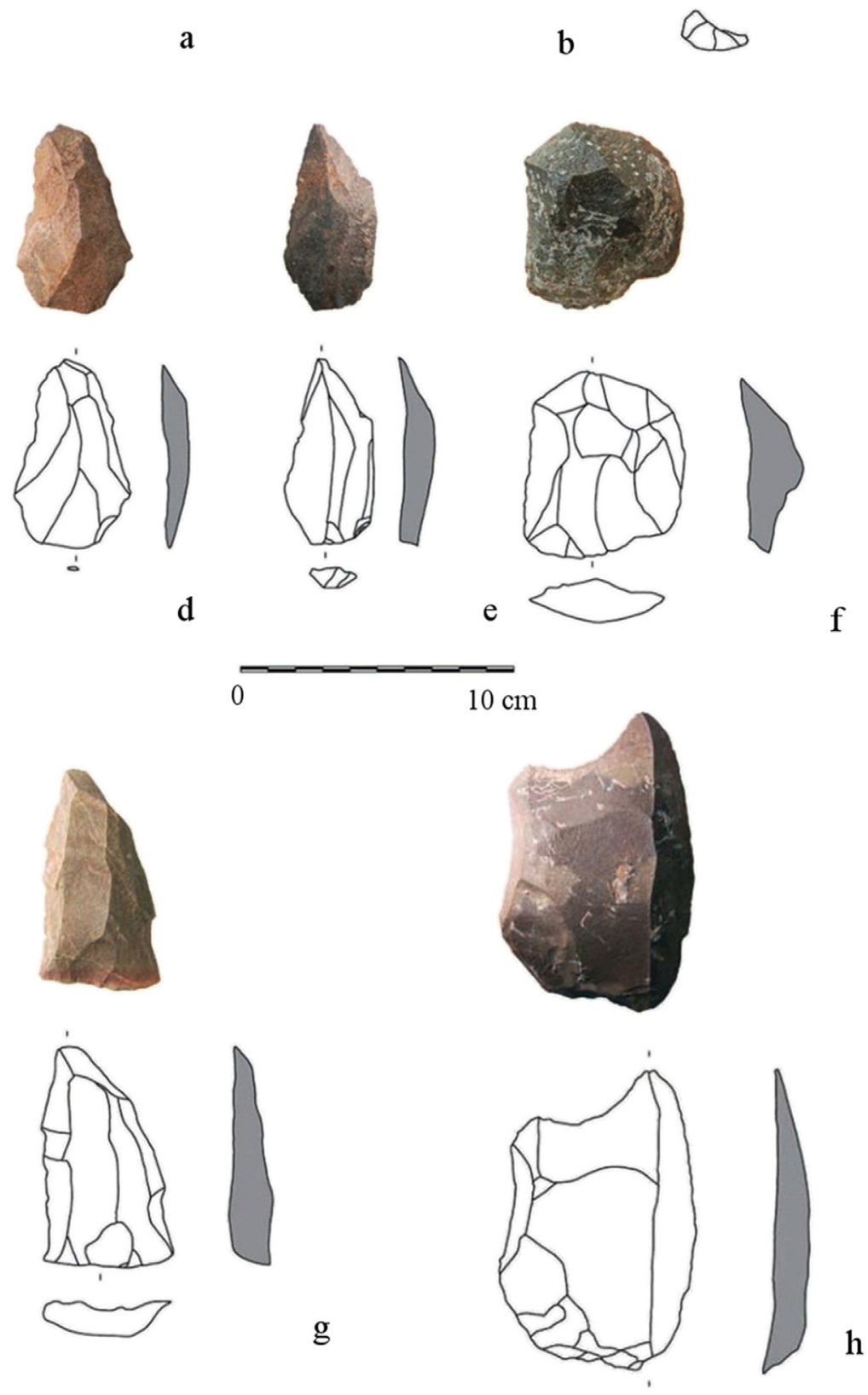

Fig. 5. BP: Levallois flakes. (a-b) Level 1, (c-e) Level 2, (f-g) Level 3. 

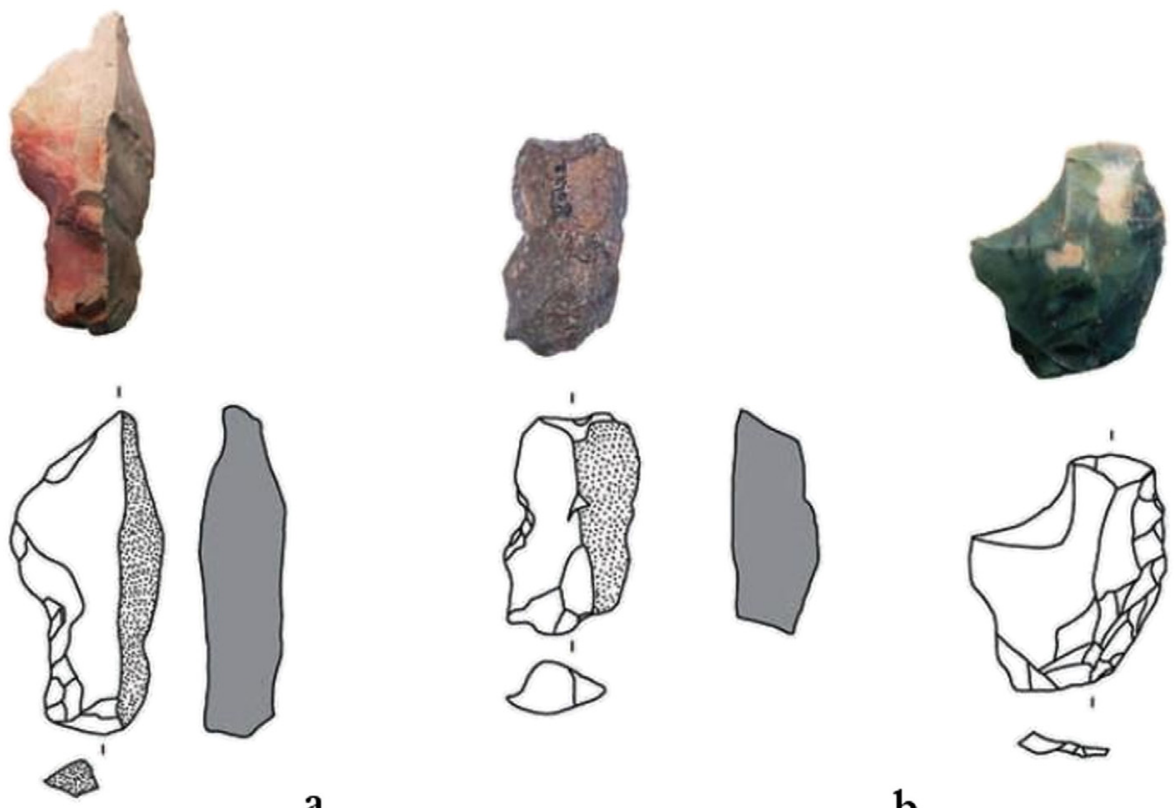

a

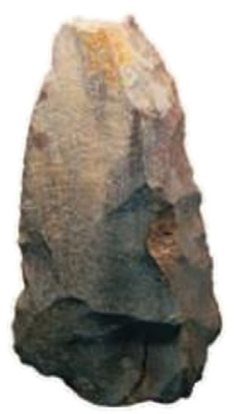

0

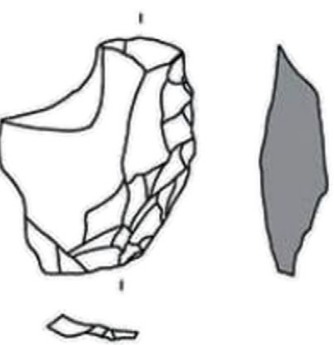

b
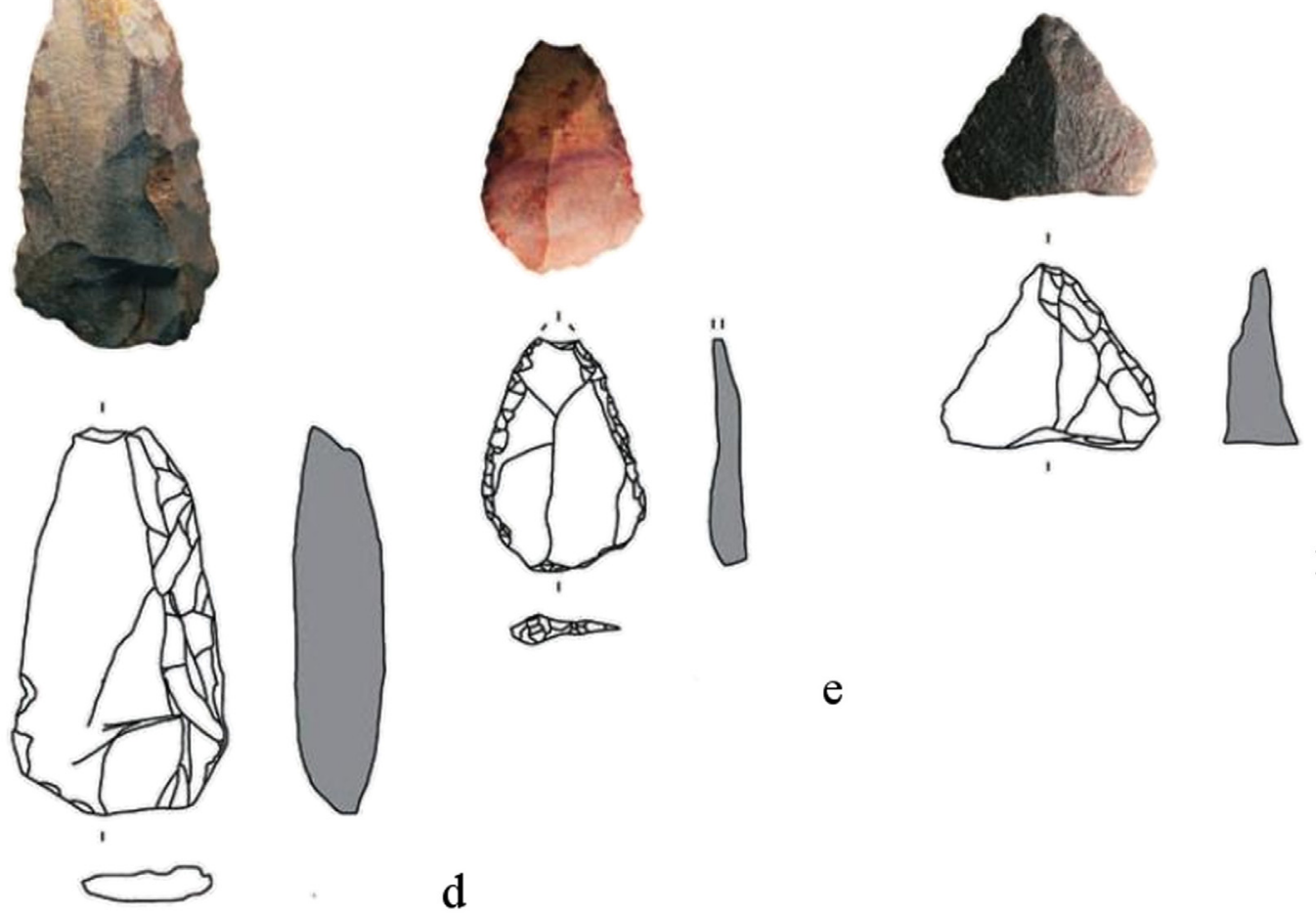

f

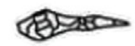

e

d

Fig. 6. BN2G: Retouched pieces. Notches (a-c), scrapers (d-f). Level 4.

The cooperative project carried out by the Institut National des Sciences de l'Archéologie et du Patrimoine (INSAP, Rabat) and the Kommission für Archäologie Ausereuropäischer Kulturen (KAAK, Bonn) des Deutschen Archäologischen Instituts in the eastern Rif (Mikdad et al., 2000, 2004; Eiwanger, 2001, 2004; Mikdad and Eiwanger, 2005; Linstädter et al., 2012) is also yielding good results, as are the projects initiated in northern Morocco by the universities of Cádiz and Abdelmalek Esaadi (Tétouan) and INSAP (Rabat) (Ramos et al., 2008b, 2011b), the cooperative project carried out in Tangier by INSAP and Université de Liège (Bouzouggar, 2003;
Otte et al., 2004), and the project run by the University of the Basque Country in the region of Tiris (Sáenz de Buruaga, 2008, 2014).

These international projects have found new Middle Palaeolithic sites in caves, rock-shelters and open-air locations, and great progress is being made with regard to the chronostratigraphy of North African Late Middle and Upper Palaeolithic contexts. Especially important are the stratified sites of Ifri El Baroud and Ifri n'Ammar (Eiwanger, 2001, 2004; Mikdad et al., 2004; Nami and Moser, 2010) in the eastern Rif. Ifri n'Ammar presents the alternation of Middle Palaeolithic and Aterian strata, which are dated to between $171 \pm 6$ 

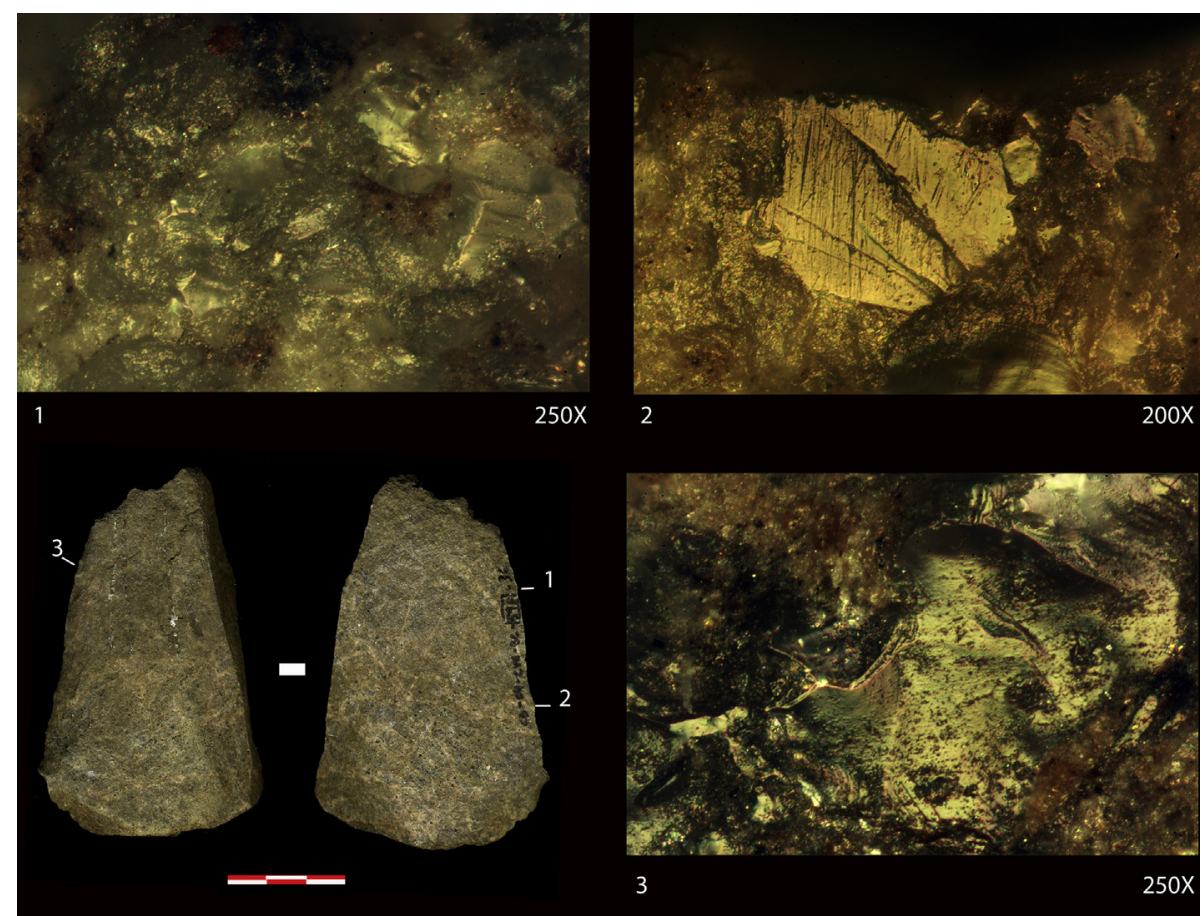

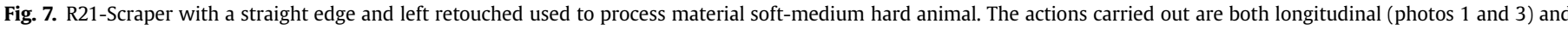
transverse (photo 2).

and $83 \pm 6 \mathrm{ka}$ (Nami and Moser, 2010: 35). According to the excavators, the industry of the site represents a distinct Mousterian facies (Linstädter et al., 2012). Also of interest is the identification of a large number of open-air sites in the Oujda hills, which are yielding considerable palaeobotanic, faunal, technological and lithological evidence (Wengler et al., 2001). The Cave of Guenfouda (Aouraghe et al., 2008), an investigation of which was begun recently, is also located in this region. Concerning the region around Tétouan, considerable evidence related to Mode 3 Middle Palaeolithic technologies has been attested on alluvial terraces (Ramos et al., 2008b, 2011b). The excavations that are being carried out in the Cave of Taforalt - another example of international cooperation (between

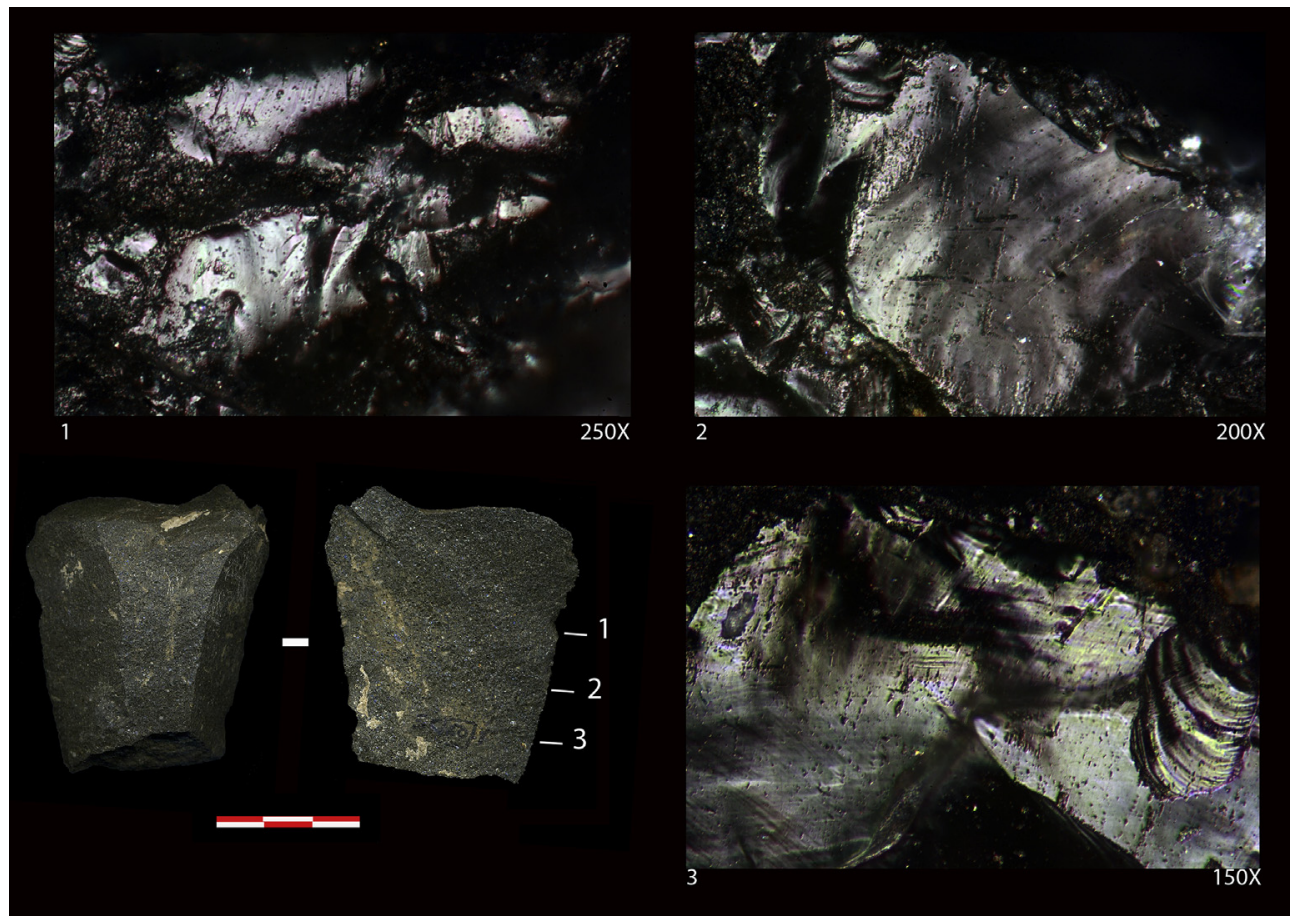

Fig. 8. Use wear at scraping wood in the surface of the tool (R21-Scraper). 


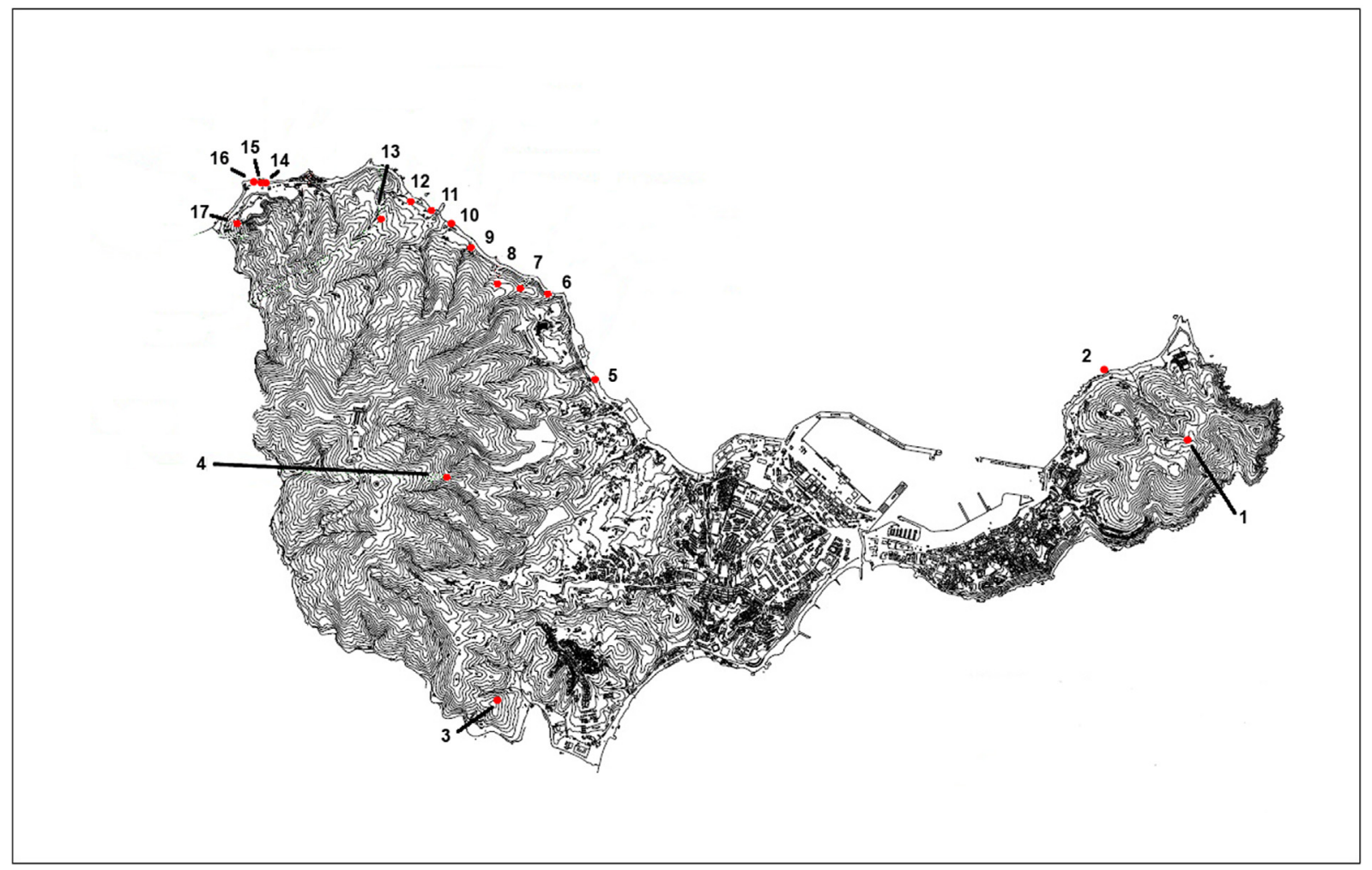

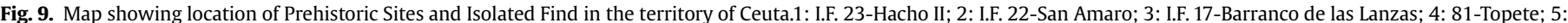

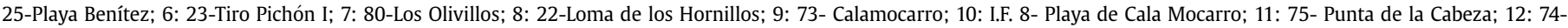
Altabacal; 13: 80-Los Olivillos; 14: 76-Zapatero III; 15: I.F. 33-Casa de Zapatero V; 16: I.F. 32-Casa de Zapatero IV; 17: Rock-shelter of Benzú.

INSAP and the University of Oxford) - are also expected to have positive results (Bouzouggar and Barton, 2005, 2012).

All of this evidence clearly indicates the presence of Mode 3 Middle Palaeolithic industries in North Africa. Although the number of stratified sites identified is low, the expansion of research to areas such as central Tunisia, the Algerian coast and both western and eastern Morocco has provided an increasing amount of evidence for Mode 3 technologies dating to the Middle

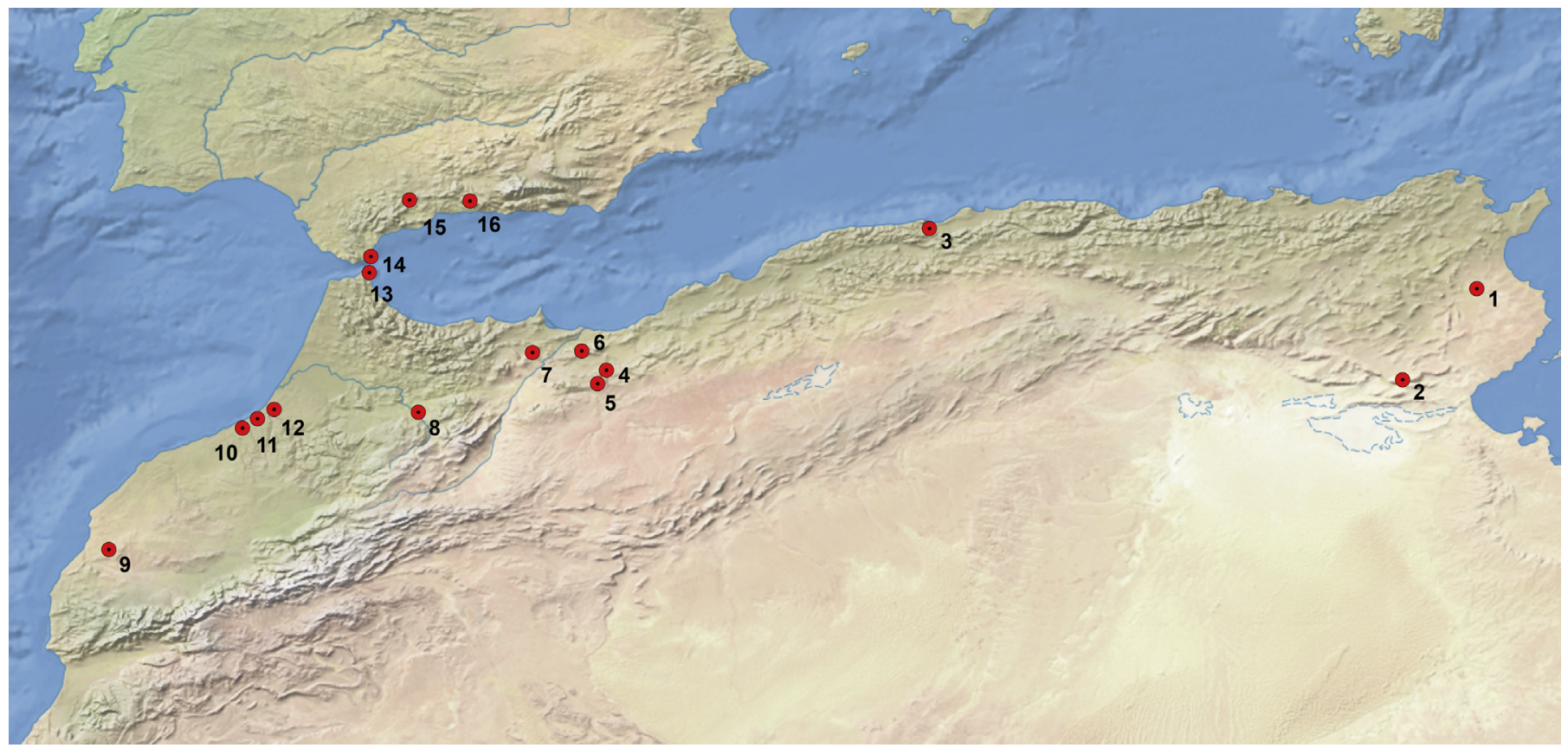

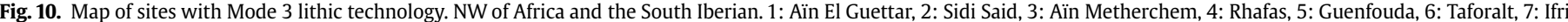

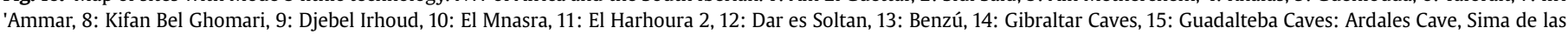
Palomas, 16: Deposits of the Axarquía. 
Pleistocene. Work is being done in Aïn Metherchem (Hajri, 2007), Aïn El Guettar (Belhouchet and Aouadi, 2007) and Témara, El Mnasra, El Harhoura 2 (Nespoulet et al., 2008a, 2008b, 2011; El Hajraoui and Nespoulet, 2012) and Dar es Soltane (Barton et al., 2009). Chronologies obtained in Benzú - - $254 \pm 17$ ka BP (stratum 2) and 70 ka BP (stratum 7): Ramos et al., 2008b, 2013b; 2011b - suggest a high chronology for Mode 3 technologies and find confirmation in other sites, for example Ifri n'Ammar - between $171 \pm 12$ and $83 \pm 6 \mathrm{ka}$ (Nami and Moser, 2010: 35) - and Djebel Iroud - between 190 and 106 ka (Grün and Stringer, 1991; Smith et al., 2007).

The human groups attested for the Iberian Peninsula in these chronologies are regarded as descendants from the Homo heidelbergensis and the Homo sapiens neanderthalensis (De Lumley, 1998: 131; Arsuaga et al., 2001; Garralda, 2005-2006; Barroso, C., Lumley, H. De, 2006; Walker et al., 2008; Finlayson et al., 2008; Finlayson, 2009; Zilhao et al., 2010; Baena et al., 2014). Initially, it was believed that North Africa was colonised by groups of Neanderthals during this period, but later studies suggest that these groups were early Homo sapiens sapiens (Hublin, 1989; Debénath, 2001; Zouak, 2001: 154) related to Aterian technology (Zouak, 2001: 155; 2007). It is hoped that the recent research burst will be a means of collecting further technological and anthropological evidence for these groups and their possible relationship with groups on the Iberian Peninsula.

Based on the available evidence, Mode 3 Mousterian Middle Palaeolithic technology in North Africa can be ascribed a high chronology (starting over $200 \mathrm{ka}$ ). This is in contrast to chronologies recorded in the south of the Iberian Peninsula, which are lower (Finlayson et al., 2006; Wood et al., 2013).

Research has to tackle significant problems: for example the relationship between mode 2 and mode 3 technologies, the origins of Aterian technologies and the alternation of Aterian and Middle Palaeolithic technologies (Dibble et al., 2013) in sites such as Sidi Said (Tipasa, Algeria) (Hajri, 2007) and Ifri n'Ammar (Nami and Moser, 2010: 35). These problems are associated with that of the occupation of the southern Iberian Peninsula, which is itself a problem. One fact can hardly be denied in the light of recent evidence: Mode 3 Mousterian Middle Palaeolithic contexts in North Africa are older.

\section{Human diversity in the framework of a similar technological and economic framework on both shores of the Straits of Gibraltar}

The chronology of Mode 3-Middle Palaeolithic in the Iberian Peninsula (Barroso and De Lumley, 2006; Finlayson et al., 2006; Cortés et al., 2012) is more recent than that of MSA-MiddlePalaeolithic in NW Africa (Nami and Moser, 2010; Bouzouggar and Barton, 2012; Linstädter et al., 2012; Dibble et al., 2013). Palaeo-environmental evidence in both regions shows some similarities, as recently demonstrated by archaeo-botanical analyses (Ruiz Zapata and Gil, 2013, 2014, 2015; Uzquiano, 2013).

The similarity of Mode 3 Middle Palaeolithic technologies in the south of the Iberian Peninsula (Cortés et al., 2011-2012: 77) and in North Africa (Nami and Moser, 2010; Linstädter et al., 2012; CollinaGirard and Bouzouggar, 2013; Ramos et al., 2013b) must be stressed. In both regions, these technologies are characterised by the production of scrapers and Mousterian points, and also by the techniques used in their production, including core preparation and preliminary flaking. In our opinion, these technical similarities are more than mere polygenic convergence, and must be explained in terms of sociocultural relationships. These contacts could have taken place during cold Pleistocene phases, when the coastlines were closer to one another (Collina-Girard, 2001; Flemming et al.,
2003; Rodríguez Vidal et al., 2004; Abad et al., 2013; CollinaGirard and Bouzouggar, 2013).

The direct analysis of sites in the south of the Iberian Peninsula region of Axarquía (Malaga) (Ramos, 1988), Cadiz's Atlantic coast (Ramos, 2008) and the region of Guadalteba (in cooperation with Gerd Weniger) (Medianero et al., 2011; Kehl et al., 2013; Weniger and Ramos, 2014) -, the rock-shelter of Benzú (Ramos et al., 2013b) and the region around Tétouan (Ramos et al., 2008b, 2011b) in North Africa demonstrated the similarity between cores, flakes and retouched products on both shores. Furthermore, the evidence suggests that the techniques used for their production were also very similar. On the other hand, both the mode of organisation of these societies (Otte, 1995) and their nomadic lifestyle (Weniger, 1991; Estévez et al., 1998) would have created plentiful opportunities for social contact and the dissemination of technology.

In addition, the evidence suggests that the similarities did not stop at technology; recent studies indicate that Middle and Upper Pleistocene societies on both shores of the Straits of Gibraltar exploited marine resources (Finlayson, 2009; Zilhao et al., 2010; Colonese et al., 2011; Cortés et al., 2011; Ramos and Cantillo, 2011; Ramos et al., 2011a; Cantillo, 2012). In the south of the Iberian Peninsula, these activities were carried out by Neanderthal groups (Stringer et al., 2008; Finlayson, 2009; Cortés et al., 2011), whereas in North Africa these activities, as well as Middle Palaeolithic and Aterian technologies, are thought to have been performed by Homo sapiens sapiens (Hublin, 1989; Zouak, 2001, 2007; Garcea, 2004; Barton et al., 2008). Mode 3 technologies and the exploitation of marine and coastal resources are documented in association in both regions (Cortés et al., 2011; Ramos and Cantillo, 2011; Ramos et al., 2011a). In our opinion (Arteaga et al., 1998; Ramos, 1999), the evidence indicates that the groups on both shores of the Straits of Gibraltar practised the same activities, even if they have traditionally been interpreted separately.

\section{Acknowledgments}

We wish to thank the editors of this volume and the anonymous reviewers for their suggestions, which have greatly contributed to improving our work. Also, we want to offer out warmest thanks to all of our colleagues in Benzú and Carta Arqueológica del Norte de Marruecos.

\section{References}

Abad, M., Rodríguez-Vidal, J., Ruiz, F., López-González, N., Chamorro, S., Bernal, D., Ramos, J., 2007. Rasgos morfológicos y bioerosivos en un alto nivel marino del Pleistoceno Medio: El Abrigo arqueológico de la Cabililla de Benzú (Ceuta). In: Lario, J., Silva, P.G. (Eds.), XII Reunión Nacional de Cuaternario, AEQUA, Ávila, pp. 69-70.

Abad, M., Rodríguez-Vidal, J., Aboumaria, K., Zaghloul, M.N., Cáceres, L.M., Ruiz, F., Martínez-Aguirre, A., Izquierdo, T., Chamorro, S., 2013. Evidence of MIS 5 sealevel highstands in Gebel Mousa coast (Strait of Gibraltar, North of Africa). Geomorphology 182, 133-146.

Aouraghe, H., Gagnepain, J., Haddoumi, H., El Hammouti, K., Ouchaou, B., Bailón, S., Mestour, B., Oujaa, A., Bouzouggar, A., Billy, A., 2008. La Grotte Préhistorique de Guenfouda, Maroc Oriental: Les premieres resultas (fouilles 2004-2007). In: Aouraghe, H., Haddoumi, H., El Hammouti, K. (Eds.), Le Quaternaire Marocain dans son contexte Méditerranéen, pp. 299-319. Actes RQM 4. Faculté des Sciences d'Oujda, Oujda.

Arsuaga, J.L., Martínez, I., Lorenzo, C., Quam, R., Carretero, M., Gracia, A., 2001. neandertales y humanos modernos en el levante peninsular. In: Villaverde, $\mathrm{V}$. (Ed.), De neandertales a cromañones. El inicio del poblamiento humano en las tierras valencianas. Universitat de Valencia, Valencia, pp. 323-326.

Arteaga, O., Ramos, J., Roos, A.M., 1998. La Peña de la Grieta (Porcuna, Jaén). Una nueva visión de los cazadores-recolectores del mediodía atlántico-mediterráneo desde la perspectiva de sus modos de vida y de trabajo en la Cuenca del Guadalquivir. In: Sanchidrián, J.L., Simón, M.D. (Eds.), Las culturas del Pleistoceno Superior en Andalucía. Patronato de la Cueva de Nerja, Málaga, pp. 75-109. 
Baena, J., Carrión, E., Torres, C., 2014. La perduración de los últimos neandertales en la Península Ibérica. In: García-Alfonso, E. (Ed.), Movilidad, contacto y cambio. Il Congreso de Prehistoria de Andalucía. Junta de Andalucía. Consejería de Educación, Cultura y Deporte, Sevilla, pp. 53-71.

Bagolini, B., 1968. Ricerche sulle dimensioni dei manufatti litici prehistorici non ritoccati. Annalli dell'Universitá di Ferrara XV I (10), 195-219.

Balout, L., 1955. Préhistoire de l'Afrique du Nord. Essai de chronologie. Arts et Métiers Graphiques, Paris.

Barroso, C., De Lumley, H. (Eds.), 2006. La Grotte du Boquete de Zafarraya. Málaga, Andalousie. Junta de Andalucía, Cedma, Unicaja, Caja Granada. Muséum National d'Histoire Naturelle, IPH, Centre Européen de Recherches Préhistoriques de Tautavel, Laboratoire Départemental de Préhistoire du Lazaret, Sevilla, p. 1743.

Barton, R.N., Bouzouggar, A., Collcutt, S., Gale, R., Higham, T., Malek, F., Parfitt, S., Rhodes, E., Stringer, C., 2005. The Late Upper Palaeolithic occupation of the Moroccan northwest Maghreb during the Last Glacial Maximum. African Archaeological Review 22 (2), 77-100.

Barton, R.N., Bouzouggar, A., Lubell, D., 2008. Modern human dispersals, environments and cultural change in the Late Pleistocene of Nortwest Africa. African Archaeological Review 25, 1-2.

Barton, R.N., Bouzouggar, A., Collcutt, S., Schwenninger, J.L., Clark-Balzan, L., 2009 OSL dating of the Aterian levels at Dar es-Soltan I (Rabat, Morocco) and implications for the dispersal of modern Homo sapiens. Quaternary Science Review 28, 1914-1931.

Bateman, M., Calado, D., 2003. Análisis por O.S.L. de dos muestras del Abrigo de Benzú. In: Ramos, J., Bernal, D., Castañeda, V. (Eds.), El Abrigo y la Cueva de Benzú en la Prehistoria de Ceuta, Consejería de Educación y Cultura de Ceuta, UNED Ceuta. Universidad de Cádiz, Cádiz, pp. 273-280.

Belhouchet, L., Aouadi, N., 2007. Nouvelles contributions à la compréhension du comportement des hommes du Paléolithique moyen en Tunisie: Etude des objets archéologiques du site de Aïn El-Guettar (Meknassy, Tunisie centrale). In Colloque International Préhistoire Maghrébine. CNRPAH, Tamanrasset, p. 17.

Benéitez, P., Millán, M.A., Ramos, J., Bernal, D., Castañeda, V., 2004. Datación absoluta por termoluminiscencia de material cerámico y carbonatos procedentes del yacimiento arqueológico de la cueva de Benzú (Ceuta). In: Felíu, M.J., Martín, J., Edreira, M.C., Fernández, M.C., Martínez, M.P., Gil, A., Alcántara, R. (Eds.), Avances en Arqueometría 2003. Servicio de Publicaciones de la Universidad de Cádiz, Cádiz, pp. 17-24.

Bernal, D., Lorenzo, L., Castañeda, V., Ramos, J., 2003. La Carta Arqueológica de Ceuta. Historiografía y resultados de la prospección del año 2001. Registro y yacimientos prehistóricos. In: Ramos, J., Bernal, D., Castañeda, V. (Eds.), E Abrigo y la Cueva de Benzú en la Prehistoria de Ceuta. Consejería de Educación y Cultura de Ceuta, UNED Ceuta. Servicio de Publicaciones de la Universidad de Cádiz, Cádiz, pp. 77-159.

Bernal Gómez, M.A., 2012. Los comportamientos técnicos líticos durante el Paleolítico Medio en Gibraltar (MIS 5 al 3) y su contextualización en el extremo sureste de la Península Ibérica. Tesis de Master Inédita. Universitat Rovira i Virgili, Tarragona.

Binford, L.R., 1983. In Pursuit of the Past. Thames and Hudson, London.

Binford, L.R., 1985. Human ancestors: changing views of their behaviour. Journal of Anthropological Archaeology 4, 292-327.

Boëda, E., Bourguignon, L., Griggo, C., 1998. Activités de subsistance au Paléolithique moyen: couche VI3b' du gisement d'Umm el Tlel (Syrie). In: Économie préhistorique: les comportements de subsistance au Paléolithique. XVIIIe. Rencontres Internationales d'Archéologie et d'Histoire d'Antibes. APDCA, Juanles-Pins, pp. 243-258.

Bordes, F., 1976-1977. Moustérien et Aterien. Quaternaria XIX 19-34.

Bordes, F., 1978. Vingt-cinq ans après: le complexe moustérien revisité. Boulletin de la Société Préhistorique Française 75, 77-87.

Botella, M., Martínez, C., 1979. El yacimiento Musteriense de Cueva Horá (Darro Granada). Primeros resultados. Antropología y Paleoecología Humana 1, 59-93.

Bouzouggar, A. 2003. La fin du Paléolithique Moyen sur la façade atlantique marocaine entre Tánger et Rabat. Perspectives paléogéographiques. Beiträge zur Allgemeinen und Vergleichenden Archäologie 23, 75-84.

Bouzouggar, A., Barton, N., 2005. Le cadre chrono-culturel et paléoenvironnementa des occupations préhistoriques au Maroc oriental et nord-occidental au cours du Pléistocène supérieur. In: Colloque International Trente années d'archéologie marocaine, Rabat, pp. 15-16.

Bouzouggar, A., Barton, N., 2006. Les cultures préhistoriques du Maroc NordOccidentale vers la fin du Pléistocène Supérieur dans leur cadre régional. In: Bernal, D., Raissouni, B., Ramos, J., Bouzouggar, A. (Eds.), Actas del I Seminario Hispano-Marroquí de Especialización en Arqueología. Universidad de Cádiz, Cádiz, pp. 121-132.

Bouzouggar, A., Barton, N., 2012. The identity and timing of the Aterian in Morocco. In: Hublin, J.J., McPherron, S.P. (Eds.), Modern Origins: a North African Perspective. Vertebrate Paleobiology and Paleoantrhopology. Springer Science.

Bouzouggar, A., Barton, N.E., Collcutt, S.N., Parfitt, S., Higham, T., Rhodes, E., Gale, R. 2006. Le Paléolithique supérieur au Maroc: apport des sites du Nord-Ouest et de l'Oriental. In: Sanchidrián, J.L., Márquez, A.M., Fullola, J.M. (Eds.), La cuenca mediterránea durante el Paleolítico Superior. Fundación Cueva de Nerja, Málaga, pp. 138-150.

Bravo, A., Bellver, J.A., 2004. Prehistoria del Rif Oriental en la obra de Carlos Posac Mon. Instituto de Cultura Mediterránea, Melilla.

Calado, D., 2006. ¿Qué técnicas de datación se han aplicado en Benzú? In: Ramos, J., Bernal, D. (Eds.), El Proyecto Benzú 250.000 años de Historia en la orilla africana del Círculo del Estrecho. Ciudad Autónoma de Ceuta. Servicio de Publicaciones de la Universidad de Cádiz, Cádiz, pp. 104-106.

Camps, G., 1974. Les civilisations préhistoriques de l'Afrique du Nord et du Sahara (Doin, París)

Cantillo, J.J., 2012. Análisis arqueomalacológico del Abrigo y Cueva de Benzú (Ceuta). El aprovechamiento de los recursos acuáticos por sociedades prehistóricas en la región histórica del Estrecho de Gibraltar (Ph.D. thesis). University of Cadiz.

Cantillo, J.J., Soriguer, M., 2011. La explotación de los recursos marinos por las sociedades cazadoras-recolectoras-pescadoras. In: Ramos, J., Bernal, D., Cabral, A., Vijande, E., Cantillo, J.J. (Eds.), Benzú y los orígenes de Ceuta. Ciudad Autónoma de Ceuta. Museo de la Basílica Tardorromana y Universidad de Cádiz, Cádiz, pp. 103-110.

Carbonell, E., Márquez, B., Mosquera, M., Olí, A., Rodríguez, X.P., Sala, R., Vergès, J.M., 1999. El Modo 2 en Galería. Análisis de la industria lítica y sus procesos técnicos. In: Carbonell, E., Rosas, A., Díez, C. (Eds.), Atapuerca: Ocupaciones humanas y paleoecología del yacimiento de Galería. Arqueología en Castilla y León 7, Zamora, pp. 299-352.

Clemente, I., 1995. Sílex y lustre térmico en el Paleolítico Medio. ¿Alteración o técnica de talla? El ejemplo de Mediona I (Alt Penedès, Barcelona). Trabalhos de Antropologia e Etnologia 35 (3), 7-43, $1^{\circ}$ Congresso de Arqueologia Peninsular, Sociedade Portuguesa de Antropologia e Etnologia, Porto.

Clemente, I., 1997a. Thermal alterations of flint implements and the conservation of micro-wear polish: preliminary experimental observations. In: Bustillo, M.A. (Ed.), Siliceous Rocks and Culture. Universidad de Granada, Granada, pp. 525-535.

Clemente, I., 1997b. Los instrumentos líticos del Túnel VII: una aproximación etnoarqueológica. Treballs d'Etnoarqueologia II. CSIC-UAB, Barcelona.

Clemente, I., 2006. ¿Para qué se usaron esas piedras? El análisis funcional como respuesta a viejas cuestiones. In: Ramos, J., Bernal, D. (Eds.), El Proyecto Benzú 250.000 años de historia en la orilla africana del Círculo del estrecho. 30 preguntas y 10 opiniones. Ciudad Autónoma de Ceuta, Universidad de Cádiz, Cádiz, pp. 89-95.

Clemente, I., 2013. Análisis funcional de los restos líticos del Abrigo de Benzú a lo largo de 180.000 años de ocupación: una aproximación a las actividades productivas a partir de un sondeo secuencial. In: Ramos, J., Bernal, D., Vijande, E. Cantillo, J.J. (Eds.), El Abrigo y la Cueva de Benzú. Memoria de los trabajos arqueológicos de una década en Ceuta (2002-2012). Ciudad Autónoma de Ceuta. Universidad de Cádiz, Cádiz, pp. 299-315.

Clemente, I., Gibaja, J.F., 2009. Formation of use-wear traces in non-flint rocks: the case of quartzite and rhyolite. Differences and similarities. In: Sternke, F., Costa, L., Eigeland, L. (Eds.), Non-flint Raw Material Use in Prehistory: Old Prejudices and New Directions. Proceedings of the XV. Congress of the U.I.S.P.P. British Archaeological Reports International Series, 1939. Archaeopress, Oxford, pp. 93-98.

Collina-Girard, J., 2001. L'Atlantide devant le Detroit de Gibraltar? Mythe et géologie. Comptes rendues Academie des Sciences de Paris 333, 233-240.

Collina-Girard, J., Bouzouggar, A., 2013. La longue préhistoire des brassages culturels en Méditerranée. In: Hassani-Idrissi (Ed.), Méditerranée. Une histoire à partager. Bayard, Montrouge, pp. 29-57.

Colonese, A.C., Mannino, M.A., Bar-Yosef Mayer, D.E., Fa, D.A., Finlayson, J.C., Lubell, D., Stiner, M.C., 2011. Marine mollusc exploitation in Mediterranean prehistory: an overview. Quaternary International 239, 86-103.

Cortés, M., Morales, A., Simón, M.D., Lozano, M.C., Vera, J.L., Finlayson, C., RodríguezVidal, J., Delgado, F., Jiménez, F.J., Martínez, F., Martinez-Aguirre, A., Pascual, A., Bergadá, M., Gibaja, J.F., Riquelme, J.A., López, A., Rodrigo, M., Sskai, S., Sugosaki, S., Finlayson, G., Fa, D., Bicho, N., 2011. Earliest known use of Marine resources by Neanderthals. Plos One 6 (9), e24026, 1-15.

Cortés, M., Jiménez, F., Rodríguez Vidal, J., Morales, A., Simón, M.D., 2011-2012. Primeras ocupaciones humanas y fase antigua del Paleolítico Medio meridional ibérico en la Bahía de Málaga. Mainake XXXIII 63-82.

De Lumley, H., 1998. L'Homme premier. Préhistoire, Évolution, Culture. Editions Odile Jacob. Paris.

Debénath, A., 2001. La recherche Archéologique au Maroc: quelques éléments concernant le Paléolithique. In: Actes des Premières Journées Nationales d'Archéologie et du Patrimoine, vol. 1, pp. 19-23. Rabat.

Dibble, H.L., Aldeias, V., Jacobs, Z., Olszewski, D.I., Rezek, Z., Lin, S.C., AlvarezFernández, E., Barshay-Szmidt, C.C., Hallett-Desguez, E., Reed, D., Reed, K., Richter, D., Steele, T.E., Skinner, A., Blackwell, B., Doronicheva, E., El-Hajraoui, M., 2013. On the industrial attributions of the Aterian and Mousterian of the Maghreb. Journal of Human Evolution 64, 194-210.

Domínguez-Bella, S., 2004. Arqueometría, materias primas minerales, captación, distribución y consumo de recursos líticos en el yacimiento de Benzú. In: Ramos, J., Bernal, D., Castañeda, V. (Eds.), Investigación interdisciplinar en Humanidades. Excavaciones arqueológicas en el yacimiento de Benzú (Ceuta). XVI Edición de los Cursos de Verano de la Universidad de Granada en Ceuta, Ceuta, pp. 153-159.

Domínguez-Bella, S., Chamorro, S., Ramos, J., Bernal, D., 2006. Materias primas minerales y geología en el entorno del Abrigo y la Cueva de Benzú (Ceuta). In: Martínez, G., Morgado, A., Afonso, J.A. (Eds.), Sociedades Prehistóricas, Recursos Abióticos y Territorio. Universidad de Granada, Granada, pp. 119-133.

Domínguez-Bella, S., Ramos, J., Bernal, D., Vijande, E., Cantillo, J.J., Cabral, A., Pérez, M., Barrena, A., 2012. Methodological approximation to the archaeological excavation in breccia: the Benzú rock-shelter case (Ceuta, Spain). Antiquity $86,1167-1178$.

Domínguez-Bella, S., Ramos, J., Barrena, A., Cabral, A., Moreno, A., 2013. Materias primas minerales de los productos tallados. In: Ramos, J., Bernal, D., Vijande, E., 
Cantillo, J.J. (Eds.), El Abrigo y la Cueva de Benzú. Memoria de los trabajos arqueológicos de una década en Ceuta (2002-2012). Ciudad Autónoma de Ceuta, Universidad de Cádiz, Cádiz, pp. 316-338.

Durán, J.J., 2003. Geología del Abrigo de Benzú. In: Ramos, J., Bernal, D., Castañeda, V. (Eds.), El Abrigo y la Cueva de Benzú en la Prehistoria de Ceuta. Consejería de Educación y Cultura de Ceuta. UNED Ceuta, Servicio de Publicaciones de la Universidad de Cádiz, Cádiz, pp. 263-266.

Durán, J.J., 2004. Estudio de los sedimentos carbonáticos asociados a cavidades cársticas. Métodos de datación, geocronología absoluta y análisis de isótopos estables. In: Ramos, J., Bernal, D., Castañeda, V. (Eds.), Investigación interdisciplinar en Humanidades. XVI Edición de los cursos de verano de la Universidad de Granada en Ceuta. Universidad de Granada, Instituto de Estudios Ceutíes, Ciudad Autónoma de Ceuta, Ceuta, pp. 125-131.

De Lumley, H., 1969. Étude de l'outillage Moustérien de la Grotte de Carigüela (Piñar, Grenade). L'Anthropologie 73 (34), 165-206 (5-6), 325-364.

Eiwanger, J., 2001. Recherches Archéologiques dans le Rif Oriental. Projet de coopération INSAP/KAVA. Actes des 1ères Journées Nationales d'Archéologie et du Patrimoine 1, 82-89. Rabat.

Eiwanger, J., 2004. Ex occidente lux-Prähistorische Forschungen im Schatten der Sáulen des Herakles (Marokko). Expeditionen in vergessene Welten. 25 Jahre Archäologische Forschungen in Afrika, Amerika und Asien, pp. 79-102. AVA Forschungen Band 10. Linden Soft, Aachem.

El Hajraoui, M.A., Nespoulet, R. (Eds.), 2012. Préhistoire de la région de RabatTémara. Villes et Sites Archéologiques du Maroc, vol. III, p. 300. Rabat.

Ennouchi, E., 1962. Un néandertalien: l'homme du Jebel Irhoud (Maroc). L'Anthropologie 66, 279-298.

Estévez, J., Vila, A., Terradas, X., Piqué, R., Taulé, M., Gibaja, J., Ruiz, G., 1998. Cazar o no cazar, ¿es ésta la cuestión? Boletín de Antropología Americana 33, 5-24.

Finlayson, C., 2009. The Humans Who Went Extinct. Why Neanderthals Died Out and We Survived. Oxford University Press, Oxford.

Finlayson, C., Giles, F., Rodríguez-Vidal, J., Fa, D., Gutiérrez, J.M., Santiago, A., Finlayson, G., Allué, E., Baena, J., Cáceres, I., Carrión, J.S., Fernández-Jalvo, Y., Gleed-Owen, C.P., Jiménez-Espejo, F.J., López, P., López Sáez, J.A., Riquelme, J.A., Sánchez Marco, A., Giles Guzmán, F., Brown, K., Fuentes, N., Valarino, C.A., Villalpando, A., Stringer, C., Martínez-Ruiz, F., Sakamoto, T., 2006. Late survival of Neanderthals at the southernmost extreme of Europe. Nature 443, 850-853.

Finlayson, C., Fa, D.A., Jiménez-Espejo, F., Carrión, J.S., Finlayson, G., GilesPacheco, F., Rodríguez-Vidal, J., Stringer, C.,B., Martínez-Ruíz, F., 2008. Gorham's Cave, Gibraltar-The persistence of a Neanderthal population. Quaternary International 181, 64-71.

Flemming, N.D., Bailey, G.N., Courtillot, V., King, G., Lambeck, K., Ryerson, F., VitaFinzi, C., 2003. Coastal and marine palaeo-environments and human dispersal points across the Africa-Eurasia boundary. In: Brebbia, C.A., Gambin, T. (Eds.), The Maritime and Underwater Heritage. Wessex Institute of Technology Press, Southampton, pp. 67-74.

Garcea, E., 2004. Crossing deserts and avoiding seas: Aterian north africaneuropean relations. Journal of Anthropological Research 60, 27-53.

Garcea, E. (Ed.), 2010. South-eastern Mediterranean Peoples between 130,000 and 10,000 Years Ago. Oxbow Books, Oxford, p. 188.

Garralda, M.D., 2005-2006. Los neandertales en la Península Ibérica. Munibe 57 (3), 289-314.

Garriga, J., Tarradell, M., 1951. Observaciones sobre el Pleistoceno de Marruecos (Regiones de Tetuán y Ceuta). Boletín de la Real Sociedad Española de Historia Natural 9, 99-118.

Geneste, J.M., 1991. Systèmes techniques de production lithique: variations technoéconomiques dans les processus de réalisation des outillages paléolithiques. Techniques et culture 17-18, 1-35.

Giles, F., Giles Guzmán, F., Gutiérrez, J.M., Santiago, A., Finlayson, C., Rodríguez Vidal, J., Finlayson, G., Fa, D., 2012. The tools of the last neanderthals: Morphotecnical characterisation of the lithic industry at level IV of Gorham's Cave, Gibraltar. Quaternary International 247, 151-161.

Grün, R., Stringer, C., 1991. Electron spin resonance dating and the evolution of modern humans. Archaeometry 33, 153-199.

Hahn, J., 1984. Südeuropa und Nordafrika. Neue Forschungen zur Altsteinzeit. Forschungen zur Allgemeinen und Vergleichenden Archäologie 4, 1-231.

Hajri, S., 2007. Approche technologique du Paléolithique moyen de Tunisie: l'exemple de Aïn Metherchem. In: Colloque International Préhistoire Maghrébine. Résumés des interventions. CNRPAH, Tamanrasset, p. 27.

Hublin, J.J., 1989. Les origines de l'homme moderne: Europe occidentale et Afrique du Nord. In: Giacobini, G. (Ed.), Hominidae, pp. 423-430.

Jennings, R.P., Giles, F., Barteon, R.N.E., Collcutt, S.N., Gale, R., Gleed-Owen, C.P., Gutiérrez, J.M., Higham, T.F.G., Parker, A., Price, C., Rhodes, E., Santiago, A., Schweninger, J.L., Turner, E., 2009. New dates and palaeoenvironmental evidence for the Middle to Upper Palaeolithic occupation of Higueral de Valleja Cave, southern Spain. Quaternary Science Reviews 28, 830-839.

Kehl, M., Burow, C., Cantalejo, P., Domínguez-Bella, S., Durán, J.J., Klasen, N., Medianero, F.J., Ramos, J., Reicherter, K., Schmidt, C., Weniger, G.C., 2013. The Palaeolithis site Sima de las Palomas de Teba, Southern Spain-Site formation processes and Chronostratigraphy. In: Baena, R., Fernández, J.J., Guerrero, I. (Eds.), VIII Reunión de Cuaternario Ibérico. La Rinconada, Sevilla, pp. 285-289.

Kuhn, S.L., 1995. Mousterian Lithic Technology. An Ecological Perspective. Princeton University Press, Princeton.

Laplace, G., 1972. La typologie Analytique et Structurale: Base rationnelle d'étude des industries lithiques et osseuses. Colloques Nationaux C.N.R.S. 932. Banques de Données Archéologiques, pp. 91-143.
Linstädter, J., Eiwanger, J., Mikdad, A., Weniger, G., 2012. Human occupation of Northwest Africa: a review of Middle Palaeolithic to Epipalaeolithic sites in Morocco. Quaternary International 274, 158-174.

Medianero, J., Ramos, J., Palmquist, P., Weniger, G., Riquelme, J.A., Espejo, M., Cantalejo, P., Aranda, A., Pérez-Claros, J.A., Figueirido, B., Espigares, P., RosMontoya, S., Torregrosa, V., Linstäedter, J., Cabello, L., Becerra, S., Ledesma, P. Mevdev, I., Castro, A., Romero, M., Martínez-Navarro, B., 2011. The karstic site of Las Palomas (Guadalteba County, Málaga, Spain): a preliminary study of its Middle-Late Pleistocene archaeopaleontological record. Quaternary International 243, 127-136.

Mercier, N., Wengler, L., Valladas, H., Joron, J.L., Froget, L., Reyss, L., 2007. The Rhafas Cave (Morocco). Chronology of the mousterian and aterian archaeological occupations and their implications for Quaternary geochronology based on luminiscence (TL/OSL) age determinations. Quaternary Geochronology 2 (1-4), 309-313.

Mikdad, A., Eiwanger, J., 2005. 10 années de recherches maroco-allemandes au Rif oriental. In: : Colloque International Trente années d'archéologie marocaine. Rabat, pp. 21-22.

Mikdad, A., Eiwanger, J., Atki, H., Ben Ncer, A., Bokbot, Y., Hutterer, R., Linstädter, J., Mouhsine, T., 2000. Recherches préhistoriques et protohistoriques dans le Rif oriental (Maroc). Rapport préliminaire. Beiträge zur Allgemeinen und Vergleichenden Archäologie 20, 109-167.

Mikdad, A., Moser, J., Nami, M., Eiwanger, J., 2004. La stratigraphie du site d'Ifri n'Ammar (Rif Oriental, Maroc): premiers résultats sur les dépots du Paléolithique Moyen. Beitrage zur Allgemeinen und Vergleichenden Archäologie 24, 125-137.

Monclova, A., Toledo, J., Sánchez, P., 2013. El registro de fauna terrestre (mamíferos). In: Ramos, J., Bernal, D., Vijande, E., Cantillo, J.J. (Eds.), El Abrigo y la Cueva de Benzú. Memoria de los trabajos arqueológicos de una década en Ceuta (2002-2012). Ciudad Autónoma de Ceuta, Universidad de Cádiz, Cádiz, pp. 283-298.

Mora, R., Martínez, J., De La Torre, I., Casanova, J. (Eds.), 2008. Variabilidad técnica del Paleolítico medio en el sudoeste de Europa. Treballs d'Arqueologia 14. Universitat Autònoma de Barcelona, Barcelona.

Morán, C., 1941. El Paleolítico de Beni Gorfet (Marruecos). Junta Superior de Monumentos Históricos y Artísticos, Larache.

Nami, M., Moser, J., 2010. La Grotte d'Ifri N'Ammar. Le Paléolithique Moyen. Forschungen zur Archäologie Auseuropäischer Kulturen. Reicher Verlag, Wiesbaden. Band 9.

Nehren, R., 1992. Zur Prähistoire der Maghrebländer (Marokko-Algerien-Tunesien). Materialien zur Allgemeinen und Vergleichenden Archäologie 49. Verlag Philipp von Zabern. 2 vols, Mainz.

Nespoulet, R., Debénath, A., El Hajraoui, A., Michel, P., Campmas, E., Oujaa, A., Ben Ncer, A., Amani, F., Stoetzel, E., Boudad, L., 2008a. Le contexte archéologique des restes humains atériens de la région de Rabat-Témara (Maroc). apports des fouilles des grottes d'El Mnasra et d'El Harhoura 2. In: Aouraghe, H., Haddoumi, H., El Hammouti, K. (Eds.), Le Quaternaire Marocain dans son contexte Méditerranéen. Actes RQM 4. Faculté des Sciences d'Oujda, Oujda, pp. 356-375.

Nespoulet, R., El Hajraoui, A., Amani, F., Ben Ncer, A., Debénath, A., El Idrissi, A. Lacombe, J.-P., Michel, P., Oujaa, A., Stoetzel, E., 2008b. Palaeolithic and Neolithic occupations in the Témara Region (Rabat, Morocco): recent data on Hominin contexts and behavior. African Archaeological Review 25, 21-39.

Nespoulet, R., El Hajraoui, A., Debénath, A., 2011. Les recherches archéologiques dans la région de Rabat-Témara, une région fortement urbanisée et touristique. In: Bernal, D., Raissouni, B., Arcila, M., Youbi Idrisi, M., Ramos, J., Zouak, M., López, J.A., Maatouk, M., El Khayari, A., El Moumni, B., Ghottes, M., Azzariohi, A. (Eds.), Arqueología y turismo en el Círculo del Estrecho. Universidad de Cádiz, Diputación de Cádiz, Dirección Regional de Cultura Tánger-Tetuán, Cádiz, pp. 627-645.

Otte, M., 1995. Processus éducationnels au paléolithique. In: Ulrich, H. (Ed.), Man and Environment in the Palaeolithic. ERAUL 62, Liège, pp. 335-339.

Otte, M., Bouzouggar, A., Kozlowski, J., 2004. La Préhistoire de Tanger (Maroc). Eraul 105. Université de Liège, p. 195.

Pericot, L., Tarradell, M., 1962. Manual de Prehistoria Africana. Instituto de Estudios Africanos. Consejo Superior de Investigaciones Científicas, Madrid.

Posac, C., 1956. Las industrias prehistóricas del Marruecos oriental. In: Crónica del IV Congreso Internacional de Ciencias Prehistóricas y Protohistóricas. Zaragoza, pp. $163-168$.

Posac, C., 1981. Estudio Arqueológico de Ceuta. Ceuta, p. 64.

Ramos, J., 1988. El poblamiento prehistórico del Alto Vélez hasta la Edad del Bronce. Diputación Provincial de Málaga, Málaga.

Ramos, J., 1999. Europa prehistórica. Cazadores y recolectores. Sílex, Madrid.

Ramos, J. (Ed.), 2008. Memoria del proyecto de investigación La ocupación prehistórica de la campiña litoral y banda atlántica de Cádiz. Arqueología Monografías, Junta de Andalucía, Sevilla.

Ramos, J., Cantillo, J.J., 2011. La explotación de recursos marinos por sociedades del Pleistoceno Medio y Superior. Nuevas evidencias en el Estrecho de Gibraltar en el contexto mediterráneo y africano. In: Bernal, D. (Ed.), Pescar con arte. Fenicios y romanos en el origen de los aparejos andaluces. Servicio de Publicaciones Universidad de Cádiz, Cádiz, pp. 17-35.

Ramos, J., Bernal, D., Domínguez-Bella, S., Calado, D., Ruiz, B., Gil, M.J., Clemente, I., Durán, J.J., Vijande, E., Chamorro, S., 2008a. The Benzu rockshelter: a Middle Palaeolithic site on the North African coast. Quaternary Science Reviews 27, 2210-2218. 
Ramos, J., Zouak, M., Vijande, E., Cantillo, J.J., Pérez, M., Domínguez-Bella, S. Maate, A., 2008b. Carta Arqueológica del Norte de Marruecos (campaña 2008). Primeros resultados de las ocupaciones de sociedades prehistóricas. In: Bernal, D., Raissouni, B., Ramos, J., Zouak, M., Parodi, M. (Eds.), En la orilla africana del Círculo del Estrecho. Historiografía y proyectos actuales. Colección de Monografías del Museo Arqueológico de Tetuán II. Cádiz, pp. 265-311.

Ramos, J., Zouak, M., Bernal, D., Raissouni, B. (Eds.), 2008c. Las ocupaciones humanas de la cueva de Caf Taht el Ghar (Tetuán). Los productos arqueológicos en el contexto del Estrecho de Gibraltar. Servicio de Publicaciones Universidad de Cádiz, Servicio de Publicaciones Diputación de Cádiz, Dirección Regional de Cultura Tánger-Tetuán Reino de Marruecos, Cádiz, p. 299.

Ramos, J., Domínguez-Bella, S., Cantillo, J.J., Soriguer, M., Pérez, M., Hernando, J. Vijande, E., Zabala, C. Clemente, I., Bernal, D., 2011a. Marine resources exploitation by Palaeolithic hunter-fisher-gatherers and Neolithic tribal societies in the historical region of the Strait of Gibraltar. Quaternary International 239, 104-113.

Ramos, J., Zouak, M., Vijande, E., Cantillo, J.J., Domínguez-Bella, S., Maate, A., El Idrissi, A., Cabral, A., Gutiérrez, J.M., Barrena, A., 2011b. Carta Arqueológica del Norte de Marruecos. Resultados de las ocupaciones de sociedades prehistóricas (campañas 2009 y 2010). In: Bernal, D., Raissouni, B., Arcila, M. Youbi Idrisi, M. Ramos, J., Zouak, M., López, J.A., Maatouk, M., El Khayari, A., El Moumni, B., Ghottes, M., Aaariohi, A. (Eds.), Arqueología y turismo en el Círculo del Estrecho. Colección de Monografías del Museo Arqueológico de Tetuán III. Cádiz, pp. 53-94.

Ramos, J., Bernal, D., Cabral, A., Vijande, Cantillo, J.J. (Eds.), 2011c. Benzú y los orí genes de Ceuta. Ciudad Autónoma de Ceuta, Museo de la Basílica Tardorromana. Universidad de Cádiz, Cádiz.

Ramos, J., Bernal, D., Vijande, E., Cantillo, J.J., Cabral, A., Barrena, A., DomínguezBella, S., Rodríguez, J., Chamorro, S., Durán, J.J., Abad, M., Calado, D., Ruiz, B. Gil, M.J., Clemente, I., Uzquiano, P., Soriguer, M., Monclova, A., Toledo, J., 2012. E Abrigo de Benzú (Ceuta). Aportaciones al conocimiento de las sociedades con tecnología de Modo III en la región histórica del Estrecho de Gibraltar. Mainake XXXIII 159-186.

Ramos, J., Cabral, A., Barrena, A., Vijande, E., Cantillo, J.J., Narbona, M., Pérez, A. 2013a. La tecnología lítica tallada en la secuencia del Abrigo. In: Ramos, J., Bernal, D., Vijande, E., Cantillo, J.J. (Eds.), El Abrigo y la Cueva de Benzú. Memoria de los trabajos arqueológicos de una década en Ceuta (2002-2012) Ciudad Autónoma de Ceuta, Servicio de Publicaciones Universidad de Cádiz, Cádiz, pp. 339-437.

Ramos, J., Bernal, D., Vijande, E., Cantillo, J.J. (Eds.), 2013b. El Abrigo y la Cueva de Benzú. Memoria de los trabajos arqueológicos de una década en Ceuta (20022012). Ciudad Autónoma de Ceuta, Universidad de Cádiz, Cádiz.

Ramos, J., Bernal, D., Vijande, E., Cantillo, J.J., Barrena, A., Domínguez-Bella, S., Rodríguez Vidal, J., Chamorro, S., Durán, J.J., Abad, M., Calado, D., Ruiz Zapata, B. Gil, M.J., Clemente, I., Uzquiano, P., soriguer, M., Monclova, A., Toledo, J. Almisas, S., 2014a. The Benzu rockshelter (Ceuta). Stratigraphic sequence and record of Hunter Gatherer societies of marine resources with Mode 3 technology in North Africa. In: Sala, R. (Ed.), Pleistocene and Holocene HunterGatherers in Iberia and the Gibraltar Strait. Universidad de Burgos, Fundación Atapuerca, Burgos, pp. 503-505.

Ramos, J., Bernal, D., Vijande, E., Cantillo, J.., Barrena, A., Domínguez-Bella, S. Clemente, I., Rodríguez-Vidal, J., Chamorro, S., Durán, J.J., Abad, M., Calado, D. Ruiz Zapata, B., Gil, M.J., Uzquiano, P., Soriguer, M., Monclova, A., Toledo, J., Almisas, S., 2014b. L'Abri de Benzu (Ceuta). Un site avec une technologie de Mode 3-Paléolithique moyen dans le Nord de l'Afrique. Comptes Rendus Palevol $14,43-61$.

Ramos Fernández, J., Douka, K., Pike, A.W., Thomas, L., Van Calsteren, P., Zilhao, J. 2011-2012. Dating of the Middle to Upper Paleolithic transition at the Abrigo 3 del Humo (Málaga, Spain). Mainake XXXIII, pp. 275-284.

Rodríguez Vidal, J., Cáceres, L.M., Finlayson, J.C., Gracia, F.J., Martínez, A., 2004 Neotectonics and shoreline history of the Rock of Gibraltar, southern Iberia. Quaternary Science Reviews 23 (18-19), 2017-2029.

Rots, V., 2010. Prehension and Hafting Traces on Flint Tools. A Methodology. Leuven University Press, Leuven.

Rots, V., Van Peer, P. 2006. Early evidence of complexity in lithic economy: core-axe production, hafting and use at Late Middle Pleistocene site 8-B-11, Sai Island (Sudan). Journal of Archaeological Science 33, 360-371.

Ruhlmann, A., 1951. La Grotte préhistorique de Dar es-Soltan. Institut des Hautes Études Marocaines (Collection Hespéris XI, Paris).

Ruiz Zapata, M.B., Gil, M.J., 2013. Reconstrucción del paisaje vegetal en el contexto del yacimiento de Benzú: Análisis polínico de las cuadrículas BVII y CVI (Campaña del 2007). In: Ramos, J., Bernal, D., Vijande, E., Cantillo, J.J. (Eds.), E Abrigo y la Cueva de Benzú. Memoria de los trabajos arqueológicos de una década en Ceuta (2002-2012). Ciudad Autónoma de Ceuta. Universidad de Cádiz, Cádiz, pp. 267-277.

Ruiz Zapata, M.B., Gil, M.J., 2014. Estudio polínico de la secuencia. In: Weniger, G.-C., Ramos, J. (Eds.), Sima de las Palomas de Teba 2011-2014. Intervenciones arqueológicas. Ediciones Pinsapar. Málaga, pp. 67-77.
Ruiz Zapata, María Blanca, Gil García, María José, 2015. El paisaje vegetal durante el Pleistoceno superior-Holoceno en la región del Estrecho de Gibraltar, 97 a. Fundación Tierras del Sur, Sevilla, p. 108.

Sáenz De Buruaga, A., 2008. Contribución al conocimiento del pasado cultural del Tiris. Sahara Occidental. Inventario del Patrimonio Arqueológico. Gobierno Vasco, Vitoria-Gasteiz.

Sáenz De Buruaga, A., 2014. Nuevas aportaciones al conocimiento del pasado cultural del Tiris, Sahara Occidental. Inventario del Patrimonio Arqueológico, Gobierno Vasco, Vitoria-Gasteiz.

Schwenninger, J.L., Collcutt, S.N., Barton, N., Bouzouggar, A., Clark-Balzan, L., El Hajraoui, M.A., Nespoulet, R., Debénath, A., 2010. A New Luminiscence Chronology for Aterian Caves Sites on the Atlantic Coast of Morocco. In: Garcea, E. (Ed.), South-eastern Mediterranean Peoples between 130,000 and 10,000 Years Ago. Oxbow Books, pp. 18-36.

Smith, T., Tafforeau, P., Reid, D., Grün, R., Eggins, S., Boutakiout, M., Hublin, J.J., 2007. From the Cover: Earliest evidence of modern human life history in North African early Homo sapiens. Proceedings, National Academy of Science 104 (15), $6128-6133$.

Stiner, M., Kuhn, S.L., 1992. Subsistence, technology and adaptative variation in Middle Paleolithic Italy. American Antrohopologist 94, 306-339.

Stringer, C., Finlayson, C., Barton, R., Fernández-Jalvo, Y., Cáceres, I., Sabin, R., Rhodes, E., Currant, A., Rodríguez Vidal, J., Giles, F., Riquelme, J.A., 2008. Neanderthal exploitation of marine mammals in Gibraltar. Proceedings, National Academy of Science 105 (38), 14319-14324.

Tarradell, M., 1958. Kaf Taht el Gar, cueva neolítica en la región de Tetuán (Marruecos). Ampurias XIX-XX (1957-58), pp. 137-166.

Tarradell, M., Garriga, J., 1951. El Paleolítico del río Martín. Memorias del Servicio de Arqueología del Protectorado, Tetuán.

Uzquiano, P., 2013. La evidencia antracológica, paisaje vegetal, recursos y aprovechamiento en el Abrigo Pleistoceno. In: Ramos, J., Bernal, D., Vijande, E., Cantillo, J.J. (Eds.), El Abrigo y la Cueva de Benzú. Memoria de los trabajos arqueológicos de una década en Ceuta (2002-2012). Ciudad Autónoma de Ceuta, Universidad de Cádiz, Cádiz, pp. 278-282.

Vallespí, E., 1986. El Paleolítico Inferior y Medio en Andalucía. In: Homenaje a Luis Siret (1934-1984). Junta de Andalucía, Sevilla, pp. 59-66.

Vaufrey, R., 1955. La Préhistoire de l'Afrique T I: Le Maghreb. Masson, París.

Vega, L.G., Hoyos, M., Ruiz, A., Laville, J., 1988. La séquence de la grotte de la Carihuela (Pínar, Grenada). Chronoestratigraphie et paléoecologie du Pleistocéne Supérieur au sud de la Péninsule Ibérique. In: Otte, M. (Ed.), L'Homme de Néandertal 2. L'environnement. Université de Liège, Liège, pp. 147-180.

Vijande, E., Cantillo, J.J., Cabral, A., Ramos, J., Bernal, A., Barrena, A., 2011. Benzú en su territorio. In: Ramos, J., Bernal, D., Cabral, A., Vijande, E., Cantillo, J.J. (Eds.), Benzú y los orígenes de Ceuta. Ciudad Autónoma de Ceuta, Museo de la Basílica Tardorromana de Ceuta. Universidad de Cádiz, Ceuta, pp. 59-74.

Villaverde, V., Eixea, A., Ríos, J., Zilhao, J., 2012. Importancia y valoración de la producción microlevallois en los niveles II y III del Abrigo de La Quebrada (Chelva, Valencia). Zephyrus LXX 13-32.

Walker, M., Gibert, J., López, M., Lombardic, A.V., Pérez-Pérez, A., Zapata, J. Ortega, A., Higham, T., Pike, A., Schwenninger, J.L., Zilhao, J., Trinkaus, E., 2008. Late Neandertals in Southeastern Iberia: Sima de las Palomas del Cabezo Gordo, Murcia, Spain. PNAS 105 (52), 20631-20636.

Wengler, L., 2001. Settlement during the Middle Paleolithic of the Maghreb. In: Conard, N. (Ed.), Settlement Dynamics of the Middle Paleolithic and Middle Stone Age. Kerns Verlag, Tübingen, pp. 65-89.

Wengler, L., Wengler, B., Brochier, J., El Azzouzi, M., Margaa, A., Mercier, N., Valladas, H., 2001. La Grotte du Rhafas (Maroc Oriental) et les recherches sur le paléolithique moyen. In: Actes des $1{ }^{\text {eres }}$ Journées Nationales d'Archéologie et du Patrimoine, Rabat, pp. 67-81.

Weniger, G., 1991. Überlegungen zur Mobilität Jägerischer Gruppen im Jungpaläolithikum. Saeculum 42 (1), 82-103.

Weniger, G., Ramos, J. (Eds.), 2014. Sima de las Palomas de Teba 2011-2014 (Intervenciones arqueológicas. Ediciones Pinsapar, Málaga).

Wood, R.E., Barroso, C., Caparrós, M., Jordá, J.F., Galván, B., Higham, T., 2013. Radiocarbon dating cast doubt on the late chronology of the Middle to Upper Palaeolithic transition in southern Iberia. Proceedings, National Academy of Science 110 (8), 2781-2786.

Zilhão, J., Angelucci, D., Badal, E., D'Errico, F., Daniel, F., Dayet, L., Douka, K., Higham, T.F.G., Martínez, M.J., Montes, R., Murcia, S., Pérez, C., Roldán, C. Vanhaeren, M., Villaverde, V., Wood, R., Zapata, J., 2010. Symbolic use of marine shells and mineral pigments by Iberian neandertals. Proceedings, National Academy of Science 107, 1023-1028.

Zouak, M., 2001. Origine et évolution de l'Homme au Maghreb 'Hypothèses diverses'. In: Actes des 1 ères Journées Nationales d'Archéologie et du Patrimoine, Rabat, pp. 154-156.

Zouak, M., 2007. Casablanca, des origines méconnues. In: Casablanca. Il y a un million d'années. Catalogue de l'exposition. Ministère de la Culture, Casablanca, pp. 54-59. 